\title{
The use of multibeam backscatter and bathymetry as a means of identifying faunal assemblages in a deep-sea cold seep
}

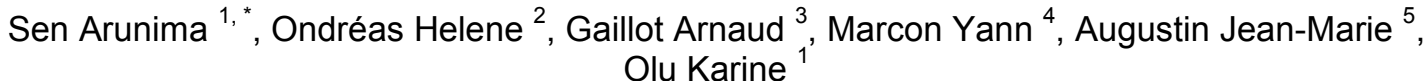

${ }^{1}$ IFREMER Centre Bretagne, Institut Carnot Ifremer-EDROME- Laboratoire Environnement Profond, Plouzané, France

2 IFREMER Centre Bretagne, Institut Carnot Ifremer-EDROME- Laboratoire Géochimie et Métallogénie, Plouzané, France

${ }^{3}$ IFREMER Centre Bretagne, Institut Carnot Ifremer-EDROME -Service Cartographie, traitement de Données et Instrumentation, Plouzané, France

${ }^{4}$ Alfred Wegener Institute, Helmholtz Centre for Polar and Marine Research, Bremerhaven, Germany

${ }^{5}$ IFREMER Centre Bretagne, Service Acoustique Sismique, Plouzané, France

${ }^{*}$ Corresponding author : Arunima Sen

\begin{abstract}
:
Deep-sea ecosystems have attracted considerable commercial interest in recent years because of their potential to sustain a diverse range of mankind's industrial needs. If these systems are to be preserved or exploited in a sustainable manner, mapping habitats and species distributions is critical. As biodiversity at cold-seeps or other deep-sea ecosystems is driven by habitat heterogeneity, imagery is the obvious choice for characterizing these systems and has indeed proven extremely valuable towards mapping biogenic habitats formed by dense aggregations of large sized species, such as coral reefs, tubeworm bushes or bivalve beds. However, the acquisition of detailed images with resolution sufficient for reliable identification is extremely time consuming, labor intensive and highly susceptible to logistical issues. We developed a novel method for quickly mapping cold seep fauna and habitats over large areas, at the scale of squares of kilometers. Our method uses multibeam echosounder bathymetry and acoustic backscatter data, both segmented and reclassified based on topographical features and then combined to obtain a raster containing unique values incorporating both backscatter and bathymetry data. Two datasets, obtained from $30 \mathrm{~m}$ and $8 \mathrm{~m}$ above the seafloor were used and the results from the two datasets were compared. The method was applied to a cold seep community located in a pockmark in the deep Congo channel and we were able to ground truth the accuracy of our method against images of the area. The two datasets, obtained from different altitudes gave varying results: the $8 \mathrm{~m}$ altitude dataset reliably predicted tubeworms and carbonate rock, while the $30 \mathrm{~m}$ altitude dataset predicted tubeworms and vesicomyid clams. The $30 \mathrm{~m}$ dataset was more accurate than the $8 \mathrm{~m}$ altitude dataset in predicting distributions of tubeworms. Overall, all the predictions were quite accurate, with at least $90 \%$ of predictions being within $5 \mathrm{~m}$ of real distributions.
\end{abstract}




\section{Highlights}

- We developed a method for mapping a deep-sea cold seep over large spatial scales. $>$ The method uses quickly obtainable multibeam bathymetry and backscatter data. Two datasets were used, from altitudes of $30 \mathrm{~m}$ and $8 \mathrm{~m}$, and the results compared. Tubeworms and carbonate were predicted from $8 \mathrm{~m}$ and tubeworms and clams from $30 \mathrm{~m}$. All predictions were highly accurate (within $5 \mathrm{~m}$ of distributions, $90 \%$ confidence).

Keywords : Mapping, Cold seeps, Multibeam, Bathymetry, Backscatter, Biogenic habitats

\section{Introduction}

Over $60 \%$ of the earth's surface is covered by more than $1000 \mathrm{~m}$ of seawater, making the deep sea the single largest ecosystem on the planet (Roberts, 2002). However, the inherent characteristics of this system, such as the presence of thousands of meters of water and its sheer extent make it difficult to produce maps of the seafloor with enough detail to understand species or habitat distributions and ecosystem dynamics. Optical imagery has been used with a considerable degree of success and has often been combined with mapping applications or Geographic Information Systems (GIS) to study benthic systems both as single snapshots in time, or over the course of repeat visits, in time-series analyses (e.g. Glover et al., 2010; Tsurumi, 1998). However, despite improvements in navigation systems that have resulted in the production of accurate maps, and improved camera and 


\section{ACCEPTED MANUSCRIPT}

video technology such as high definition devices, capturing optical images of deep-sea systems requires maintaining very low altitudes above the seafloor, in order for megafaunal species to be seen with a sufficient degree of clarity. The lower the altitude, the longer the time required for completing surveys. Therefore, resolution and spatial extent are two major costs and benefits constantly at odds with each other during deep-sea optical imaging, and increasing the spatial footprint of a survey requires major time commitments and slow speeds, if gaps in the dataset are to be avoided. Maintaining low altitudes can be quite risky in certain environments such as hydrothermal vents, where fluid emissions are highly unpredictable and can reach temperatures as high as $400^{\circ} \mathrm{C}$ (Von Damm, 1990). Optical Imagery is also highly dependent on subjective preferences or practical restraints, such as adequate lighting or additional flash sequences. Furthermore, seabed topography or even the three-dimensional structures of large benthic animals such as siboglinid polychaetes (tubeworms) found at hydrothermal vents and cold seeps can prevent the maintenance of optimal altitudes, or obstruct views.

The unfortunate consequence of the lack of reliable maps and information on deep-sea habitats and communities is that it affects the management of deep-sea resources (Roberts, 2002). Increasing industrialization and expanding economies have led to rapidly growing demands for all kinds of minerals. Terrestrial reserves are diminishing quickly and will very soon be unable to meet these demands (Baker and German, 2009; Hoagland et al., 2010; Ramirez-Llodra et al., 2011). Mineral-rich deposits on the deep-ocean floor such as polymetallic sulfides at hydrothermal vents, cobalt rich seamount crusts, or abyssal mineral nodules are likely to complement or even replace traditional mines as the source for mankind's mineral needs (Halfar and Fujita, 2007, 2002; Hannington and Monecke, 2009; Herzig and Hannington, 1995; Hoagland et al., 2010; Van Dover, 2011). Furthermore, marine oil reserves coincide with deep-sea hydrocarbon seep (also named 'cold seep') habitats, a number of deep-sea species are being vetted for various biomedical applications, and the deep sea is still considered a convenient dumping ground removed from the political and ethical limitations present on land (Fisher et al., 2007; Ramirez-Llodra et al., 2011; Rona, 2003). Subsequently, there is a 


\section{ACCEPTED MANUSCRIPT}

need for fast, efficient and reliable methods for characterizing deep-sea habitats and mapping faunal distributions, if policies and regulations regarding the management of these remote but economically and biologically important habitats are to be drafted.

Acoustic technology has the potential to be used for remote mapping of the deep seafloor over large spatial scales. Both sidescan and multibeam sonar have been used to map seafloor topography and geological features (Brown et al., 2011b; Edwards et al., 2003; Gardner et al., 2007; Micallef et al., 2007; Todd, 2005; Todd et al., 1999), archaeological artifacts and heritage sites (Jones et al., 2005; Papatheodorou et al., 2005; Singh et al., 2000) and biogenic habitats (Beaman et al., 2005; Callaway et al., 2009; Conway et al., 2005; De Falco et al., 2010; Ehrhold et al., 2006; Huvenne et al., 2005, 2011; Kostylev et al., 2003, 2001; McGonigle et al., 2009; Micallef et al., 2012; Roberts et al., 2005; Savini and Corselli, 2010; Wilson et al., 2007) in oceans around the world, at varying depths. An important reason why backscatter is so effective for seabed mapping is the high correlation between grain size and intensity of the reflected signals. In general, coarse grains are associated with high reflectivity and finer grained sediment is associated with lower reflectivity (Collier and Brown, 2005; Ferrini and Flood, 2006). Furthermore, the addition of even small amounts of larger grain sizes, such as what would be found from shell hash, can affect this correlation (Goff et al., 2000). As a result, it is possible to tease apart sediment types and biotic features from backscatter signals (Brown et al., 2011a). However, the relationship between intensity and the benthic sediment and fauna can be complex and backscatter intensity alone is not always sufficient for characterizing habitats (Ferrini and Flood, 2006). Subsequently, researchers have incorporated bathymetry data into procedures using backscatter signals for mapping the seafloor. Since both bathymetry and backscatter data can be acquired simultaneously through multibeam echosounders, recently, there has been a shift away from the use of sidescan sonar, in favor of multibeam sonar (Brown et al., 2011b; Pickrill and Todd, 2003). Data acquisition through multibeam echosounders is relatively simple and quick, even when covering large areas, which makes seafloor mapping via multibeam sonar particularly attractive within the extremely expensive field of deep-sea research. The use of multibeam acoustic data for 


\section{ACCEPTED MANUSCRIPT}

mapping deep-sea ecosystems is still in the nascent stage, and is often restricted to one type of habitat or biogenic structure, such as coral reefs (Savini and Corselli, 2010), but has already been used for mapping very specific deep-sea systems such as hydrothermal vents (Durand et al., 2006, 2002)

Our goal was to develop a semi-automated method by which datasets acquired by multibeam echosounders can be used to map and characterize deep-sea cold seep habitats formed by dense faunal aggregations. Orange et al. (2002) found that carbonate rocks and clam shells resulted in anomalous backscatter signals at cold seeps. Marcon et al. (2013a) reported a similar finding and furthermore noted that backscatter signals from an ROV mounted multibeam echosounder can be used to differentiate between sediment and areas with faunal assemblages in the Regab cold seep site off the western coast of Africa. These observations provided the impetus for this study, and the method described here combines backscatter and bathymetry data, obtained simultaneously through a multibeam echosunder, to characterize the main substrate types and faunal groups at the Regab cold seep site.

Regab is an optimal choice for this study because it hosts various habitats formed by dominant cold seep key taxa (mussels, vesicomyid clams, tubeworms), as well as different substrates (soft sediment and carbonate rock). Since the dominant faunal groups form large aggregations and potentially function as ecosystem engineers by providing substrate and refuge for other seep species, a major aim of this study was to use multibeam data to distinguish between the three major faunal groups of vestimentiferan tubeworms, mytilid mussels and vesicomyid clams. The other two important habitat types present in the Regab pockmark are carbonate rock and benthic sediment. Sediment can be reliably estimated by simple backscatter maps alone; they appear as areas of low reflectivity (Marcon et al., 2013a). However, the three faunal groups and carbonate all appear as areas of high reflectivity and therefore, the objective was to develop a method by which these four could be reliably visualized and distinguished from each other, despite having similar reflectivity signals. 


\section{ACCEPTED MANUSCRIPT}

Vestimentiferan tubeworms, mytilid mussels, vesicomyid clams and carbonate crusts are the common substrate types/habitats found in cold seeps around the world, and are often present at hydrothermal vents as well, which means that the application of the process developed here could impact the mapping of deep-sea habitats on a large scale.

\section{Methods and Materials}

\section{Study area}

The study was carried out in the $\sim 3160$ m deep Regab cold seep site off the western coast of Africa, on the passive Congo-Angola margin. Regab consists of a collection of numerous pockmarks of various depths and sizes that have been hypothesized to have been formed due to seafloor collapses during the release of highly pressurized interstitial fluids (Gay et al., 2006; Ondréas et al., 2005). Collectively, the many pockmarks form a circular depression about $20 \mathrm{~m}$ deep and 800-950 $\mathrm{m}$ wide and is known as the giant Regab pockmark (Figure 1). It is located about $8 \mathrm{~km}$ north of the Congo channel and is linked to a deep buried paleo-channel, that potentially acts as a reservoir for seeping fluids (Ondréas et al., 2005). Cores have revealed the presence of methane hydrates in the sediment and methane is present in high concentrations in the waters just above the sediment all across the pockmark (Charlou et al., 2004). The methane-rich advecting fluids support typical cold seep faunal assemblages that display highly heterogeneous spatial distributions across the pockmark (Marcon et al., 2014; Olu-Le Roy et al., 2007a). The dominant megafaunal species consist of the vestimentiferan, Escarpia southwardae (Andersen et al., 2004), the mytilid mussel, Bathymodiolus aff. boomerang (Olu-Le Roy et al., 2007b) and two species of vesicomyid clams, Christineconcha regab and Laubiericoncha chuni (Figure 2) (Krylova and Cosel, 2011; von Cosel and Olu, 2009; Von Cosel and Olu, 2008). The two clam species are difficult to differentiate through optical imagery, therefore, we did not attempt to distinguish between them and they are collectively referred to as vesicomyid clams in this study. All the dominant megafauna harbor symbiotic chemoautotrophic bacteria, from which they obtain the bulk of their nutrition (Cambon-Bonavita et al., 2009; Duperron et al., 2005). 


\section{ACCEPTED MANUSCRIPT}

Authigenic carbonate crusts, formed as a byproduct of bacterial methane oxidation, are visible in the central region of the pockmark (Ondréas et al. 2005; Pierre \& Fouquet 2007) overlapping with the distribution of B. aff. boomerang and E. southwardae (Marcon et al., 2014, 2013a; Olu-Le Roy et al., 2007a). Overall, three types of carbonate concretions occur at Regab : partly buried massive carbonate crusts that can form thick elevations ranging from several centimeters to a few meters around sediment covered depressions (often associated with vestimentiferan tubeworm assemblages), broken or displaced carbonate crusts in areas of disturbed seafloor (often associated with bivalves), and carbonate crusts fossilizing fluid conduits within the sediment (Marcon et al., 2013a; Ondréas et al., 2005; Pierre and Fouquet, 2007). The thicker carbonate crusts are concentrated in the center and the northernmost portion of the pockmark, where they cover an area of a few hundred square meters. The visible limits of carbonate crusts at Regab are described in Ondréas et al. (2005). In the central portion of the pockmark, this limit roughly corresponds with the extent of the OTUS mosaic described later (Marcon et al., 2014). For the sake of convenience, carbonate crusts, precipitates, rocks, slabs and concretions are often referred to simply as carbonate within this study. 


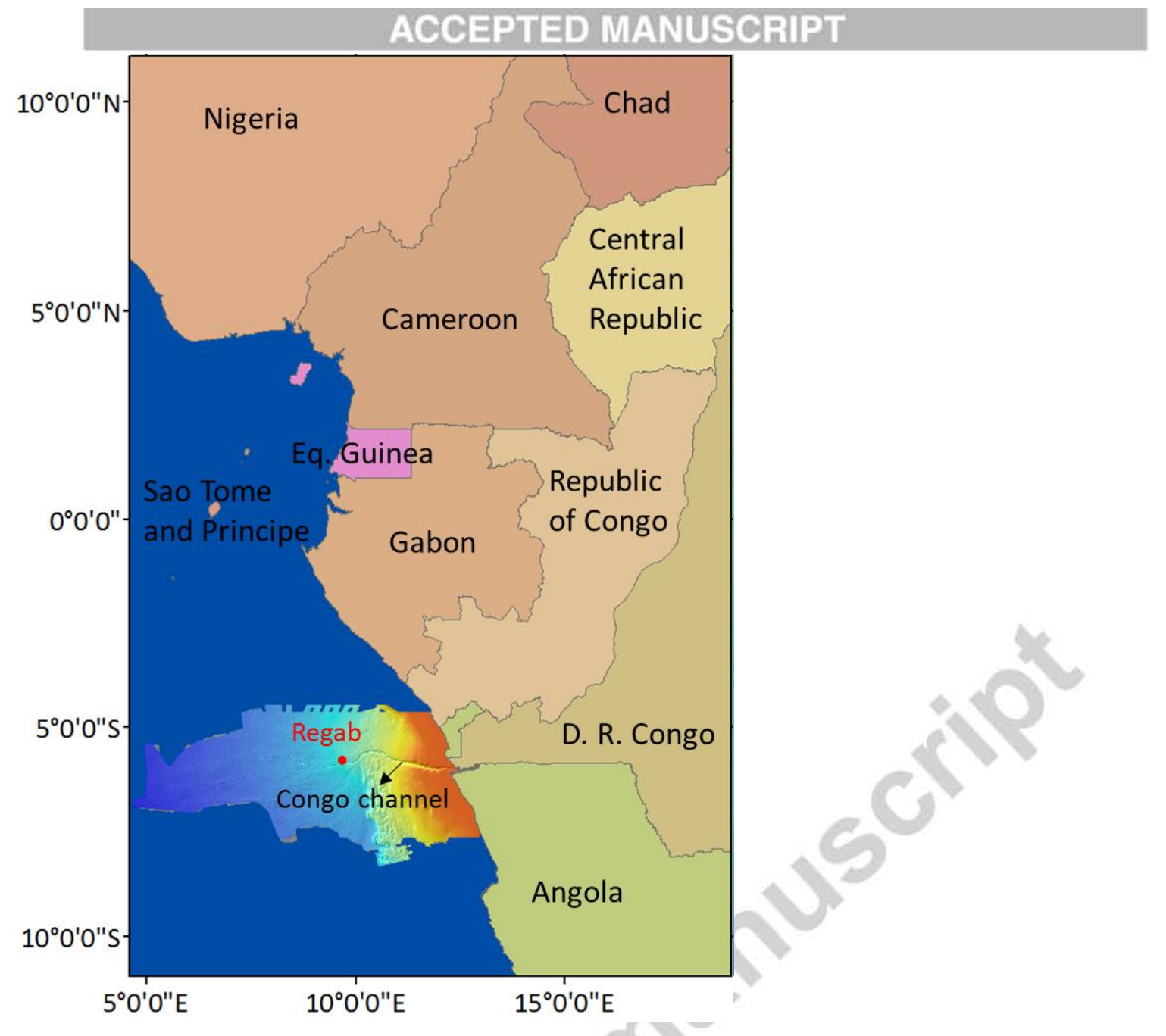

Figure 1: The location of the giant Regab pockmark, within a bathymetric map of a portion of the Gulf of Guinea. 

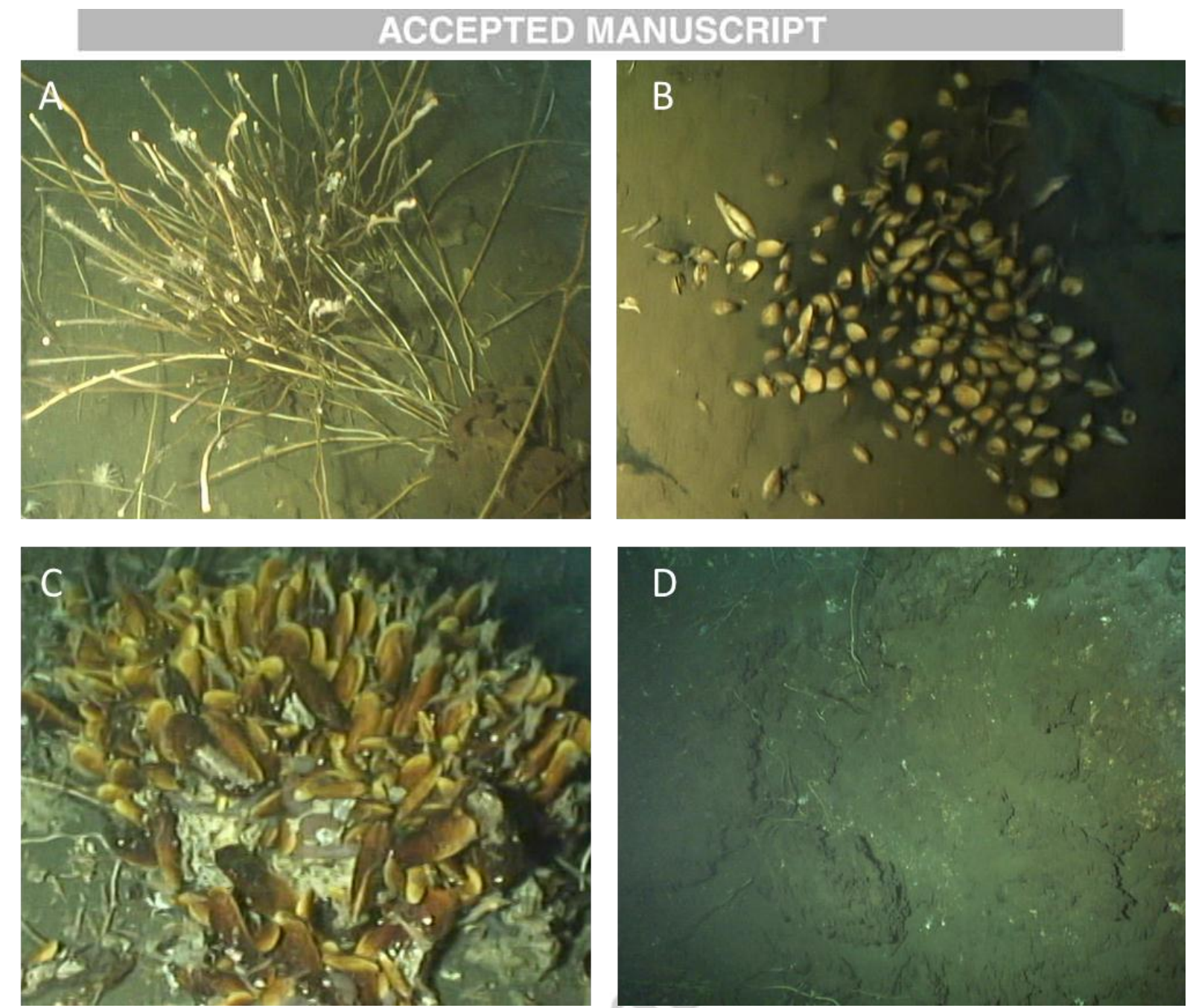

Figure 2: The three dominant megafaunal groups present at Regab: (A) Escarpia southwardae

vestimentiferan tubeworms (B) Vesicomyid clams (C) Bathymodiolous aff. boomerang mussels. In addition to these three faunal groups, carbonate rock (D) is abundant at Regab.

\section{Multibeam and imagery data}

All data was collected during the West African Cold Seeps (WACS) cruise conducted in 2011 aboard the R/V Pourquoi Pas? (chief scientist, Karine Olu), through the use of the remotely operated vehicle (ROV), Victor 6000 (Simeoni et al., 2007). A Reson Seabat 7125 multibeam echosounder (MBES), running at $400 \mathrm{kHz}$ was used for acquiring bathymetry and backscatter data. Two bathymetry and backscatter datasets each were obtained: one from an altitude of $30 \mathrm{~m}$ above the seafloor, covering the entire pockmark and some surrounding areas (approximately $1.2 \mathrm{~km}^{2}$ ), and another from $8 \mathrm{~m}$ above the seafloor, covering an area of about $0.175 \mathrm{~km}^{2}$ and constituting about $35 \%$ of the whole pockmark $\left(0.5 \mathrm{~km}^{2}\right)$. The area targeted for the $8 \mathrm{~m}$ altitude survey is a southwest-northeast corridor 


\section{ACCEPTED MANUSCRIPT}

along the center of Regab, observed on prior visits, to contain rich assemblages of fauna (Marcon et al., 2014, 2013a; Olu-Le Roy et al., 2007a). Optical images of the seafloor were obtained simultaneously during the second survey, conducted at an altitude of $8 \mathrm{~m}$. The high-sensitivity black \& white OTUS camera, mounted vertically on the ROV was used for this purpose. The images provided a means by which to ground truth the predictions of substrate types and faunal groups made by the developed method.

Bathymetry and backscatter data were processed with CARAIBES, a software developed in-house at IFREMER (Le Gal and Edy, 1997). This provided raster based maps of both bathymetry and backscatter which could be manipulated in mapping software such as ArcGIS (Figure 3). The OTUS images were stitched together to create a seamless georeferenced photomosaic using the navigation data recorded by the ROV, with the LAPM tool (Figure 4) (Marcon et al., 2013b).
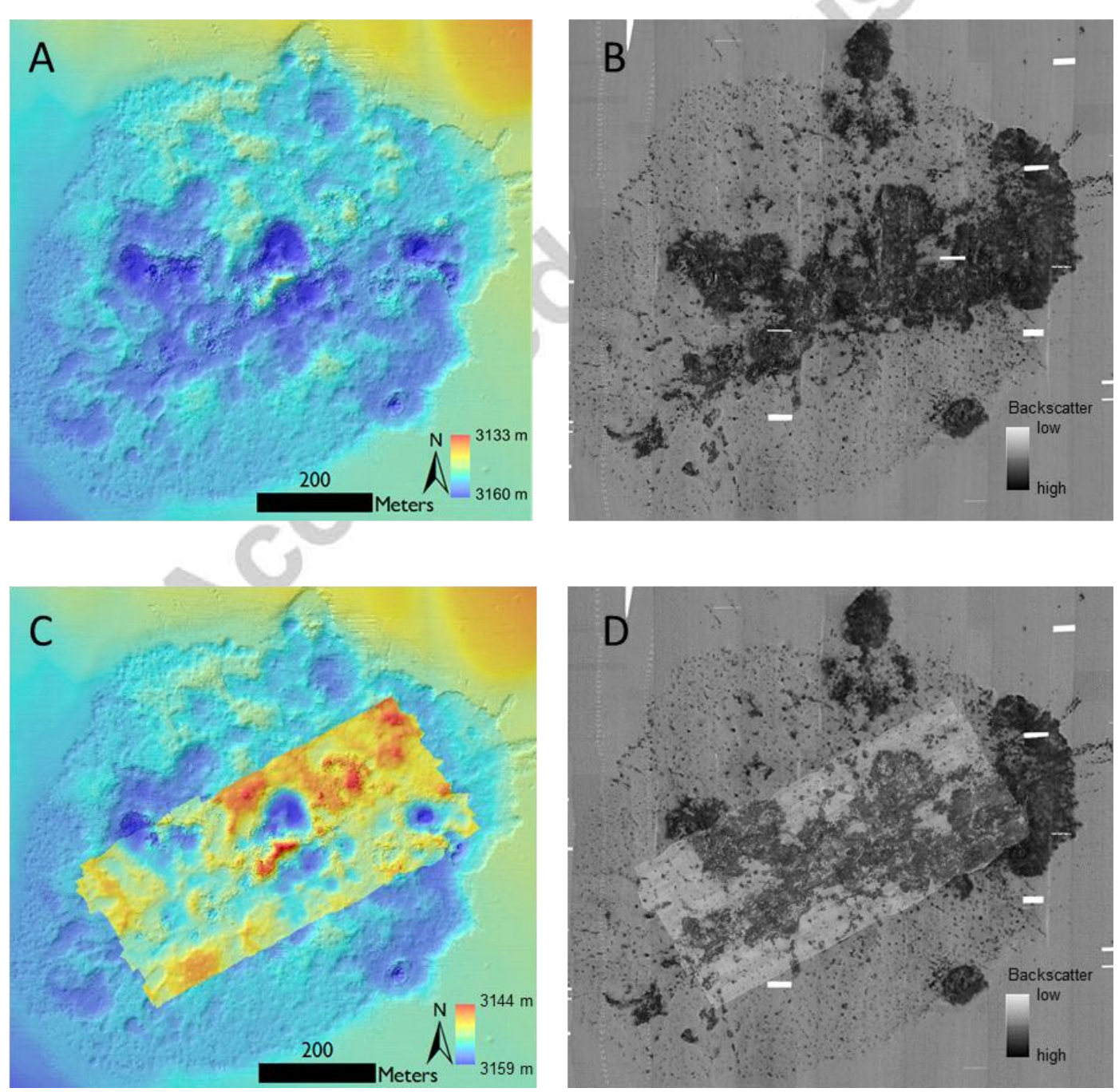


\section{ACCEPTED MANUSCRIPT}

Figure 3: Maps of Regab that were processed and used in the study. (A): Bathymetry map of the

entire pockmark, obtained from an altitude of $30 \mathrm{~m}$. (B): Backscatter map of the whole pockmark, also obtained from an altitude of $30 \mathrm{~m}$. (C): Bathymetry of the central portion of the pockmark, obtained from $8 \mathrm{~m}$ above the seafloor overlain on the bathymetry map of the whole pockmark. The legend in this figure refers to the $8 \mathrm{~m}$ altitude dataset. (D): Backscatter of the central portion of the pockmark, also obtained from an altitude of 8 am, overlain on the backscatter map of the whole pockmark.
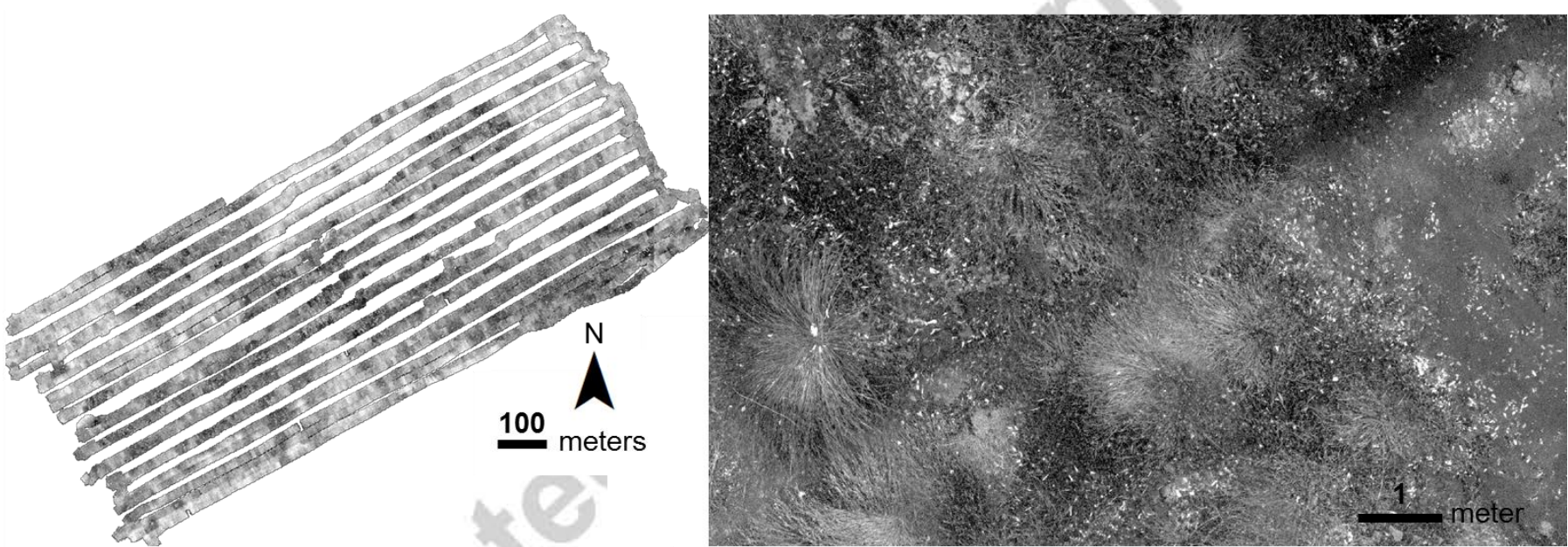

Figure 4: Photomosaic acquired through the OTUS camera from an altitude of $8 \mathrm{~m}$. On the left is the

entire photomosaic, covering an area of about $105,000 \mathrm{~m}^{2}$ (20\% of Regab) and on the right is a close up of a portion of the photomosaic.

\section{Treatment of multibeam data}

The bathymetry and backscatter raster datasets were treated based on a modified version of the methods described by Micallef et al. (2012). A flowchart of the steps is presented in Figure 5. The bathymetry map was reclassified and divided into flat and sloping areas (Figure 6). In order to achieve this, a low pass filter was first applied to the bathymetry raster dataset in ArcMap 10.2 


\section{ACCEPTED MANUSCRIPT}

(Spatial Analyst Tools >>Neighborhood >>Filter). A map of slope gradient was then calculated on this

filtered raster (Spatial Analyst Tools >>Surface >>Slope). The slope gradient raster map was then

converted to a point feature class (Conversion Tools >>From Raster >>Raster to Point) and values were exported to a text file. A graph of cumulative frequency was made with the exported file in Minitab 17 and based on the graph, the point of inflection was noted $\left(18^{\circ}\right.$ for the $8 \mathrm{~m}$ altitude dataset and $4^{\circ}$ for the $30 \mathrm{~m}$ altitude dataset, Supplementary Figure 1). In ArcMap 10.2, the slope gradient raster was then reclassified such that values less than the value at the point of inflection were classified as 'flat' and values above were classified as 'sloping' (Spatial Analyst Tools >>Reclass>>Reclassify).

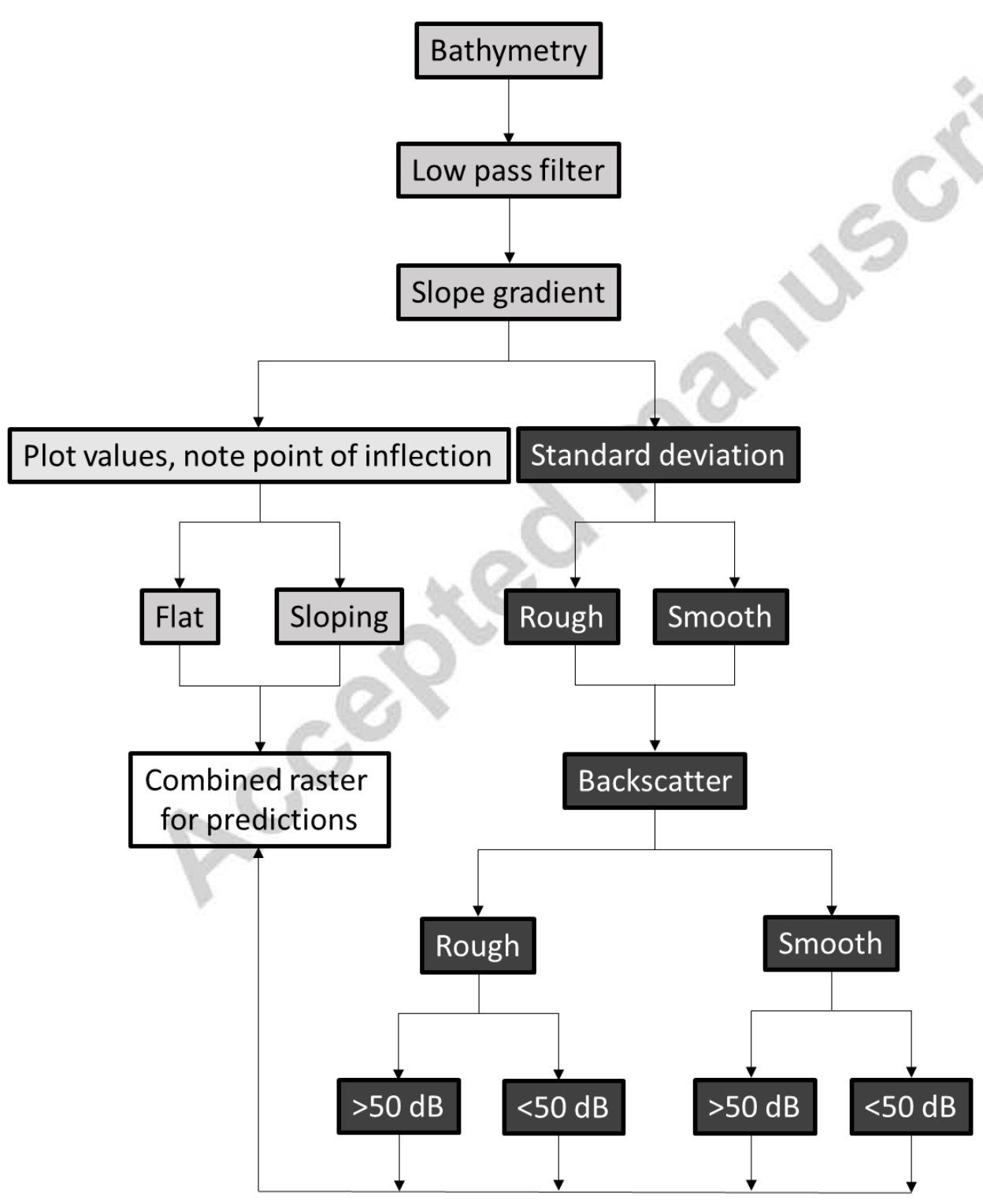

Figure 5: Flowchart of the methodology used in this study. 

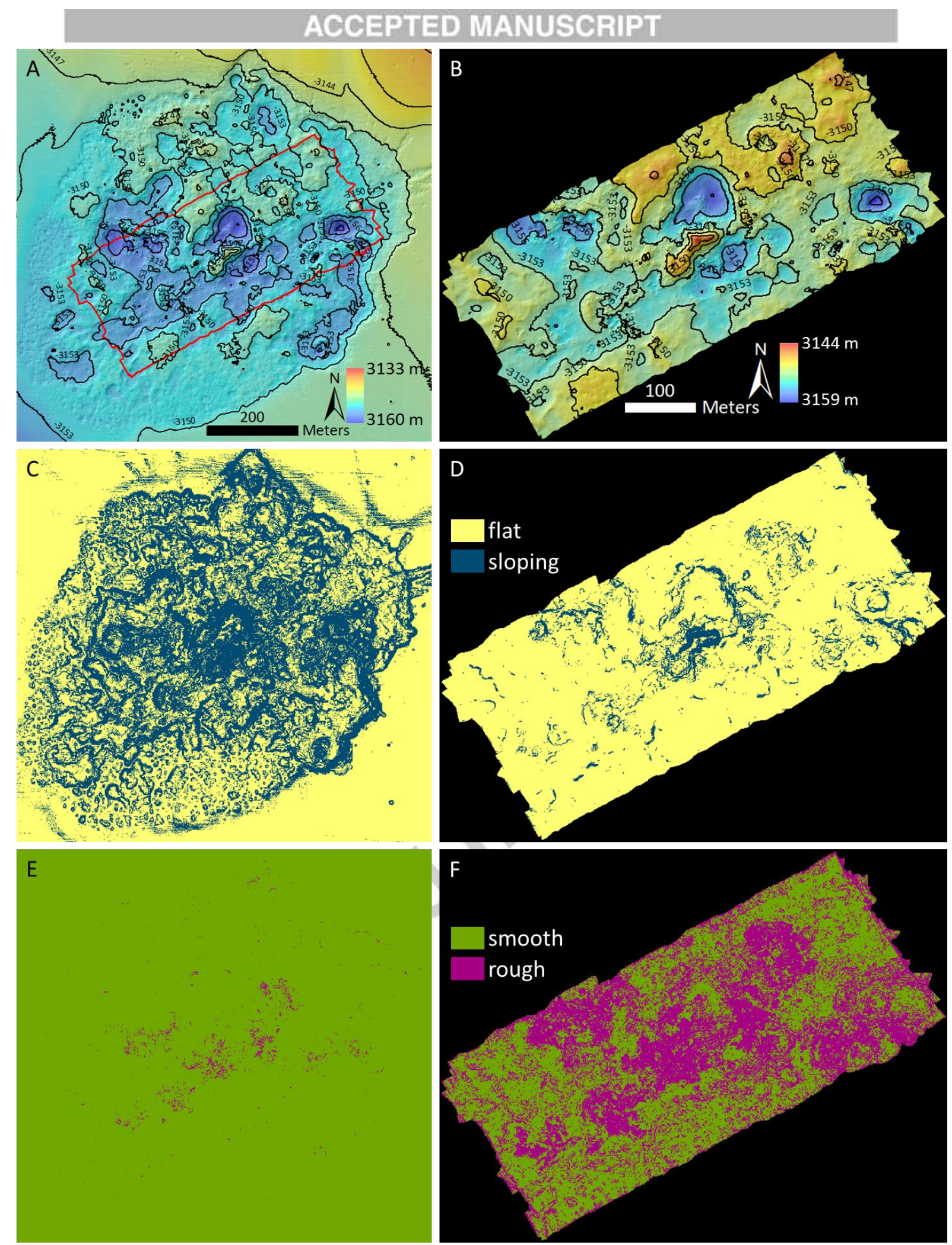

Figure 6: Depth profiles with contours of the two bathymetry maps obtained from an altitude of $30 \mathrm{~m}$ (A) and $8 \mathrm{~m}$ (B). The area covered by the $8 \mathrm{~m}$ altitude survey is outlined in red within the $30 \mathrm{~m}$ altitude bathymetry map. Bathymetry maps reclassified into flat/sloping for the $30 \mathrm{~m}$ altitude dataset 


\section{ACCEPTED MANUSCRIPT}

are displayed in $\mathrm{C}$ and for the $8 \mathrm{~m}$ altitude dataset in $\mathrm{D}$. Bathymetry maps reclassified into rough/smooth are shown in $\mathrm{E}$ for the $30 \mathrm{~m}$ altitude dataset and in $\mathrm{F}$ for the $8 \mathrm{~m}$ altitude dataset.

The slope gradient map was also used to classify areas as being either smooth or rough. Block statistics were conducted on the slope gradient raster (Spatial Analyst Tools>>Neighborhood>>Block Statistics, and Statistics type used was standard deviation) to create a map of the standard deviation of the slope gradient. The raster values were reclassified as either smooth or rough based on visually selected thresholds that corresponded to natural breaks in the histograms of obtained values. The cutoff value was 1 for the $8 \mathrm{~m}$ altitude dataset and 5 for the $30 \mathrm{~m}$ altitude dataset (Figure 6 ). The backscatter raster was then segmented based on the rough/smooth bathymetry raster. This was done with a conditional evaluation using the Con function in ArcMap 10.2 (Spatial Analyst Tools $>>$ Conditional $>>$ Con) and as a result, two complementary backscatter rasters were obtained for each backscatter dataset, one corresponding to 'rough' areas and the other corresponding to 'smooth' areas in the bathymetry datasets (Figure 7). 

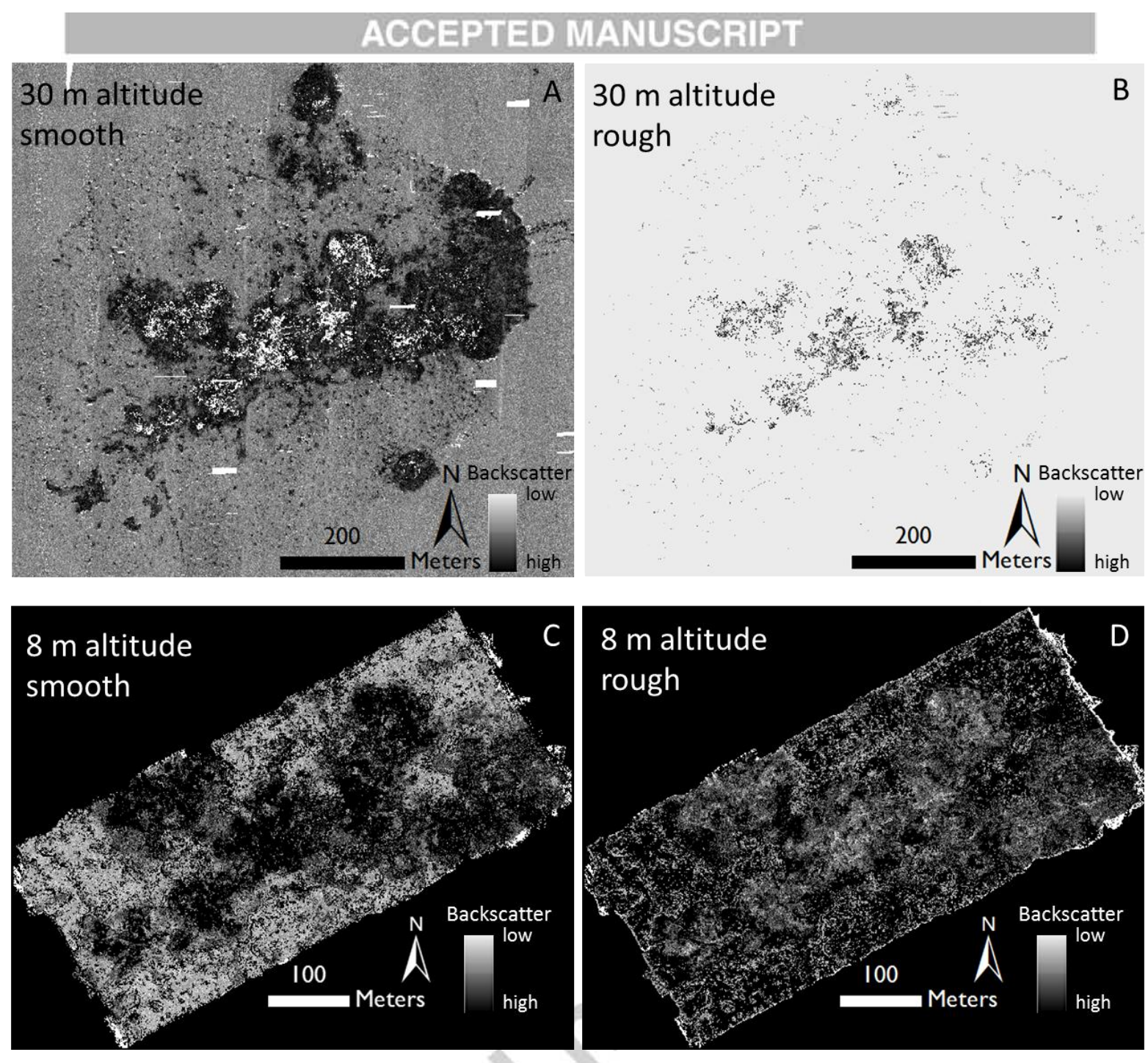

Figure 7: Backscatter maps segmented based on rough and smooth areas. A: $30 \mathrm{~m}$ altitude

backscatter dataset smooth areas. B: $30 \mathrm{~m}$ altitude backscatter dataset rough areas. C: $8 \mathrm{~m}$ altitude backscatter dataset smooth areas. D: $8 \mathrm{~m}$ altitude backscatter dataset rough areas.

The smooth and rough backscatter datasets were further segmented with SonarScope, a software developed at IFREMER for processing data acquired through multibeam echosounders and sidescan sonars. The rasters were segmented based on the distribution of values. Two peaks in the data were observed, and the data were divided into two sets of below and above $50 \mathrm{~dB}$, the value separating the two peaks. As a result, four complementary backscatter rasters were created from the two rough/smooth rasters (rough, with only values below $50 \mathrm{~dB}$, rough with only values above $50 \mathrm{~dB}$, smooth with only values above $50 \mathrm{~dB}$ and smooth with only values below $50 \mathrm{~dB}$, Figures 8-9). These 


\section{ACCEPTED MANUSCRIPT}

four rasters were combined with the flat/slope bathymetry raster to obtain one, unique raster which combined both bathymetry and backscatter data. The combined raster was cleaned using the Boundary Clean function in ArcMap 10.2 (Spatial Analyst Tools >>Generalization>>Boundary Clean) to clean ragged edges between classes by shrinking and expanding them, and a majority filter was applied (Spatial Analyst Tools>>Generalization>>Majority Filter) in order to smooth out areas by replacing cells based on the majority of contiguous neighboring cells. The cleaned and filtered combined raster (from the two different altitudes) was the final raster used to predict substrate types (Figure 10).
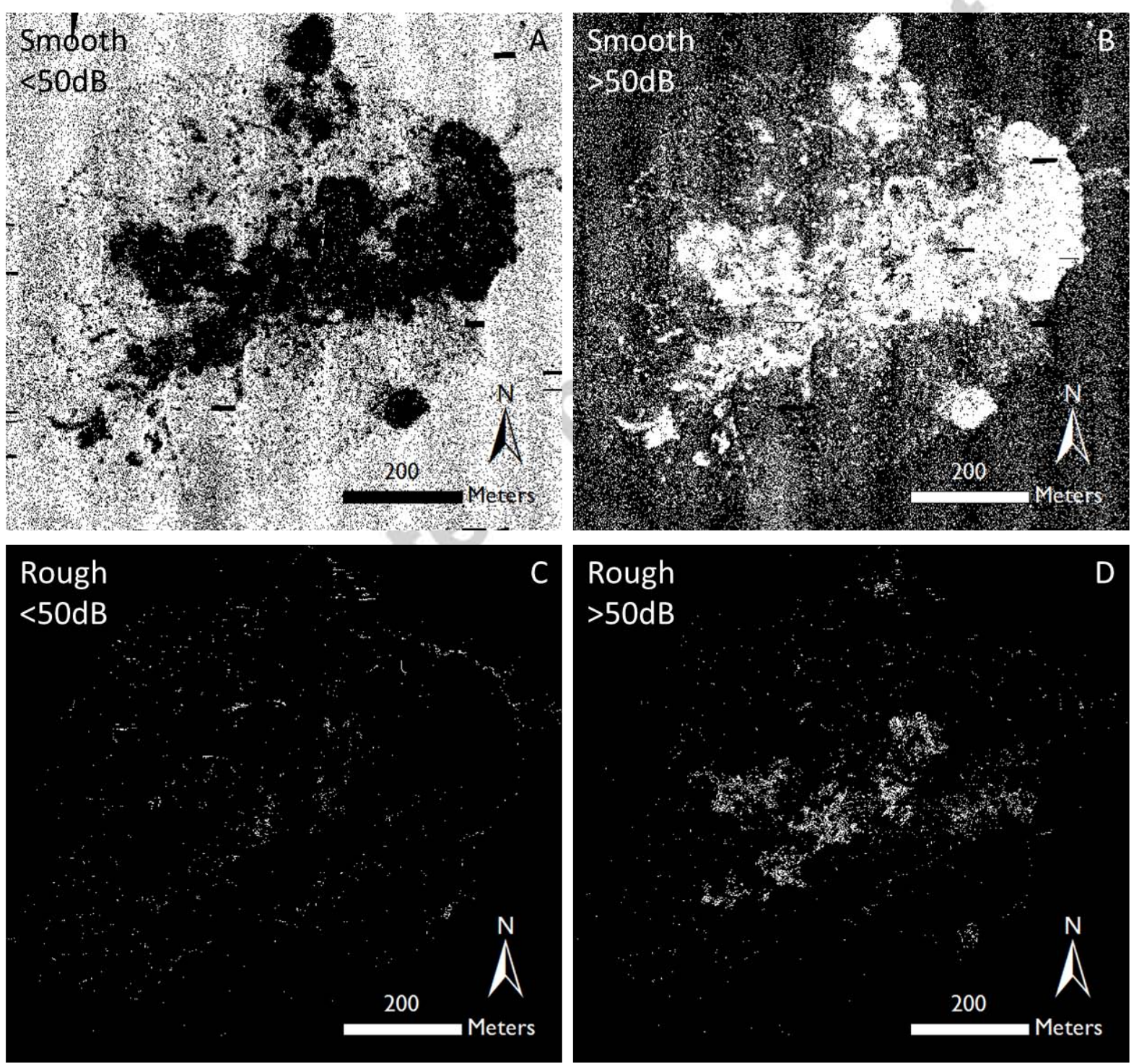

Figure 8: 'Smooth' and 'rough' backscatter maps obtained from an altitude of $30 \mathrm{~m}$, segmented

further, into values greater than and less than $50 \mathrm{~dB}$. (a): smooth areas, values less than $50 \mathrm{~dB},(\mathrm{~b})$ : 


\section{ACCEPTED MANUSCRIPT}

smooth areas, values greater than $50 \mathrm{~dB}$, (c): rough areas, values less than $50 \mathrm{~dB}$ and (c): rough areas, values greater than $50 \mathrm{~dB}$.
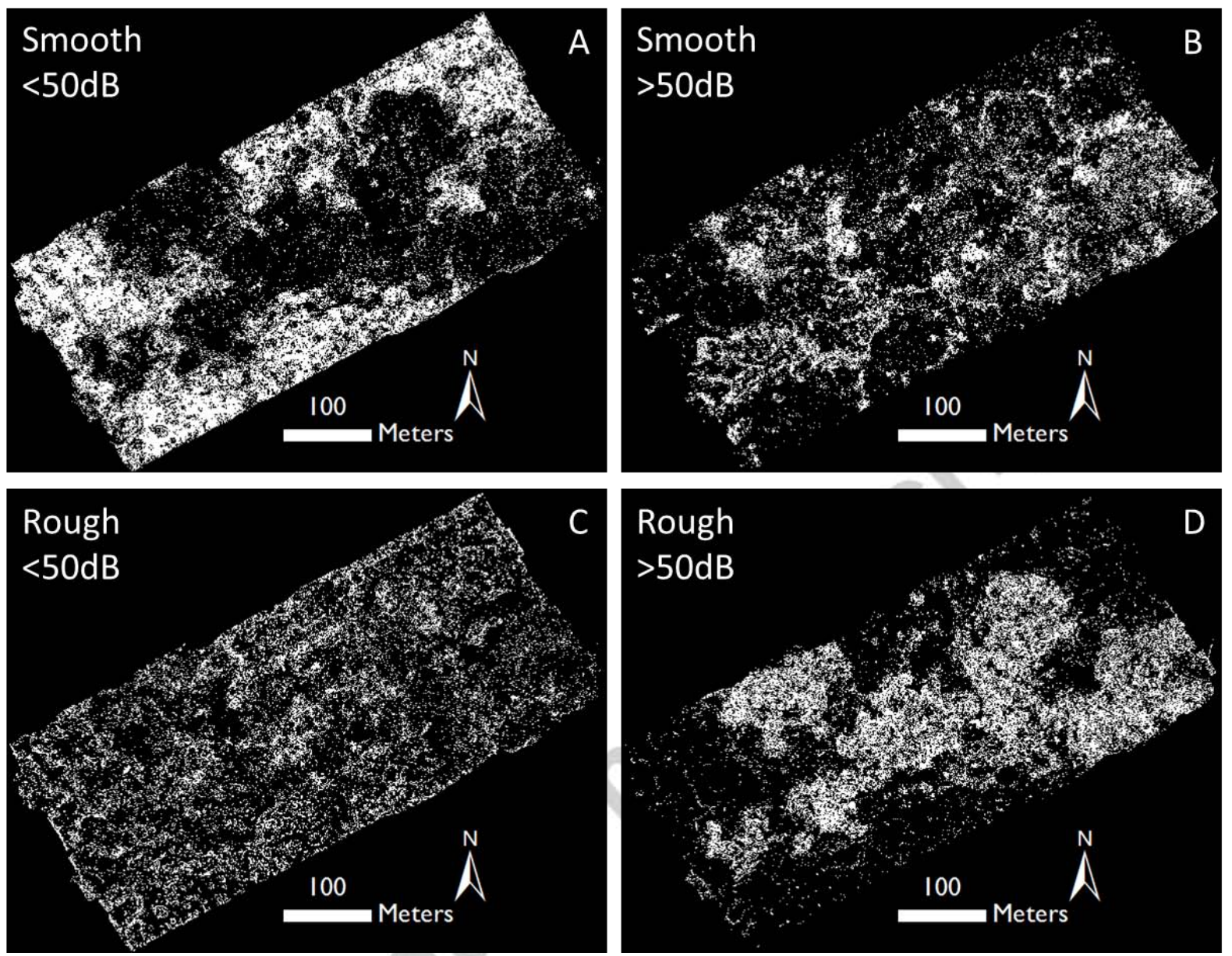

Figure 9: 'Smooth' and 'rough' backscatter maps obtained from an altitude of $8 \mathrm{~m}$, segmented

further, into values greater than and less than $50 \mathrm{~dB}$. (A): smooth areas, values less than $50 \mathrm{~dB},(B)$ :

smooth areas, values greater than $50 \mathrm{~dB},(\mathrm{C})$ : rough areas, values less than $50 \mathrm{~dB}$ and $(\mathrm{D})$ : rough areas, values greater than $50 \mathrm{~dB}$. 


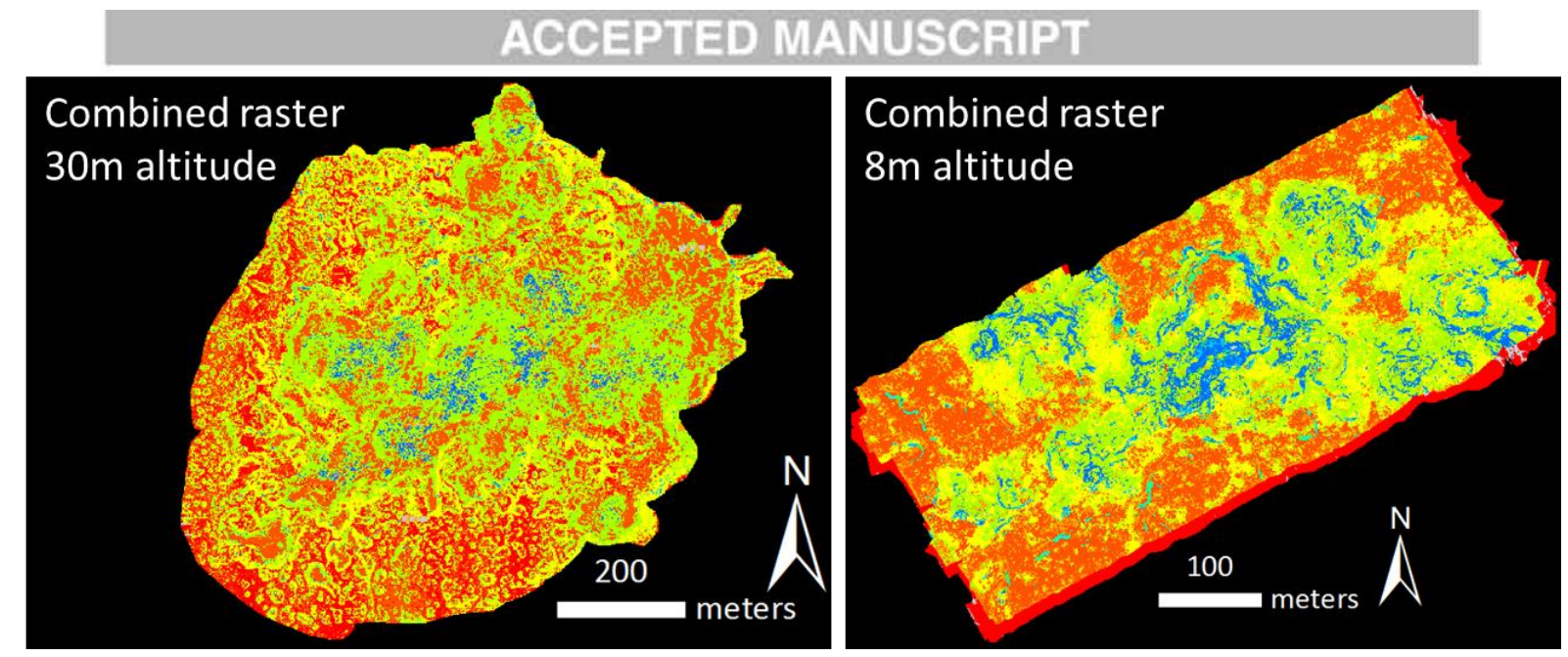

Figure 10: The combined rasters for the $30 \mathrm{~m}$ altitude dataset (left) and for the 8 am altitude dataset (right). Each combined raster outputted 14 different categories, represented by different colors.

\section{Accuracy of the method}

The accuracy of the predictions was tested by referring to the optical imagery (specifically, the OTUS mosaic and its constituent images). The four substrate/habitat types under scrutiny for this study ( $E$. southwardae tubeworms, $B$. aff. boomerang mussels, vesicomyid clams and carbonate rock) were outlined and marked in ArcMap within the georeferenced OTUS photomosaic (Marcon et al., 2013a) to facilitate comparisons between the predictions and the images (Supplementary Figure 2). The predictions were tested for the accuracy with which they predicted surface areas of the habitat types in question as well as for the locations of the predictions in relation to actual distributions. The total areas of both the predictions and the actual distributions of the four habitat types were summed up and compared in order to estimate whether the predicted areal coverage of the habitat types were comparable to actual surface areas of the habitat types. In order to test how close the predicted areas were to real aggregations and locations of substrates, the distances of the real aggregations and substrates from the predicted areas were measured. This provided an estimate of how close, in space, the predictions were to actual distributions of the fauna and substrates.

The ROV Victor 6000 uses an ultra short baseline (USBL) and dead reckoning navigation system (Simeoni et al., 2007). Since 2011, Posidonia 2 (iXBlue) is used for USBL, and the dead reckoning 
navigation system is also from iXBlue. The method consists of first starting with DGPS coordinates at the surface which serve as the initial reference point, and then using USBL positioning during the descent of the ROV. On the bottom, navigation is then based on dead reckoning along the horizontal plane. This amounts to compensating the horizontal velocities measured by an RDI Doppler velocity log for known offsets with respect to mounting angles and calibration offsets measured by a fiber optic gyrocompass. The dead reckoning navigation is automatically updated by the USBL position from time to time without loss to subsequent navigation. This repositioning minimizes the normal shift of the dead-reckoning navigation. Moreover, during this study, Victor was returned to the same marker several times and the dead reckoning was reset to that point to avoid any shift or error in the USBL position. The accuracy of the USBL system varies by water depth: it is accurate to about $0.5 \%$ of the water depth, which in the case of Regab, at a depth of about $3160 \mathrm{~m}$, equates to roughly $15 \mathrm{~m}$. For data obtained during the WACS cruise, the final navigation (dead-reckoning updated using the USBL) is 2 to 3 times better, therefore its accuracy is estimated to be $0.2 \%$ of the water depth, i.e. about $6 \mathrm{~m}$ in the case of the Regab site. Considering the kilometers of distance between the ship and the Regab study site, this possible offset of $6 \mathrm{~m}$ is remarkably low, but nonetheless should be kept in mind while viewing the validity of our results. However, this offset is only a factor to consider with the $30 \mathrm{~m}$ altitude dataset, when the bathymetry/backscatter was obtained on a separate dive from the OTUS images used for ground truthing. For the $8 \mathrm{~m}$ altitude dataset, theoretically, there is no shift or offset between the navigation associated with the bathymetry/backscatter used for the method described here and the OTUS images used for ground truthing the method since they were both acquired during the same dive and georeferenced with the same navigation file.

Since the OTUS images only covered a portion of the pockmark, the video from two other dives during the WACS cruise that surveyed areas outside the OTUS mosaic, were also consulted in order to ground truth predictions of substrate types and faunal assemblages. One of these dives (dive 429), consisted of a single transect and the mosaic created from images of this dive is similarly, a single transect, as opposed to a mosaic with side-by-side transects (Supplementary Figure 3). However, the 


\section{ACCEPTED MANUSCRIPT}

other dive (dive 423) surveyed one region of the pockmark south-west of the OTUS photomosaic in a similar manner as the OTUS survey, with overlapping images and transects. We refer to this area as WACS Mosaic 1, where a field of clams had earlier been identified (Olu-Le Roy et al., 2007a). Images from the video of these dives were extracted in 2 second intervals and the images were mosaicked together, either with the LAPM tool (for WACS Mosaic 1) or with Matisse version 3, a mosaicking software developed at IFREMER, (for dive 429) and georeferenced mosaics useable in mapping software were created of these areas.

These two photomosaics were georeferenced with navigation files from their corresponding dives (dives 423 and 429), but were used to ground truth predictions made by the described method based off of navigation obtained during a different dive, when multibeam data was collected for the whole pockmark at an altitude of $30 \mathrm{~m}$. Therefore, in this case, an offset likely exists between the photomosaics and the predictions. However, as mentioned above, based on Victor's capabilities and navigation system, this offset is likely to only be up to about $6 \mathrm{~m}$, but is nonetheless addressed in the Discussion section, in the assessment of the method described here.

Results

The combined rasters consisted of fourteen unique categories (Figure 10). The majority of these categories were either not useful in predicting substrate types and faunal assemblages and in some cases consisted of only a few pixels. However, certain categories overlapped quite well with specific substrate types and faunal groups and could be used to predict their distributions.

The combined raster obtained from data collected at an $8 \mathrm{~m}$ altitude provided reliable predictions of two habitat/substrate types: E. southwardae and carbonate rock (Figures 11-12). It was not successful at predicting the distribution of mussels or clams. This raster predicted the total coverage by $E$. southwardae to be $6520.44 \mathrm{~m}^{2}$, or, $6.14 \%$ of the OTUS photomosaic. The observed area occupied by this species was $4791.16 \mathrm{~m}^{2}$, or, $4.51 \%$ of the OTUS photomosaic (Table 1 ). About $90 \%$ of actual tubeworm aggregations were within $5 \mathrm{~m}$ of predicted aggregations (Table 2). The raster 


\section{ACCEPTED MANUSCRIPT}

predicted a total areal coverage of $27730.38 \mathrm{~m}^{2}$, or, $26.11 \%$ of the OTUS photomosaic for carbonate.

The observed coverage totaled and area of $34576.07 \mathrm{~m}^{2}$, or, $32.56 \%$ of the OTUS photomosaic. The

locations of the predictions were quite accurate: about $98 \%$ of all carbonate crusts were within $5 \mathrm{~m}$

of predicted areas.
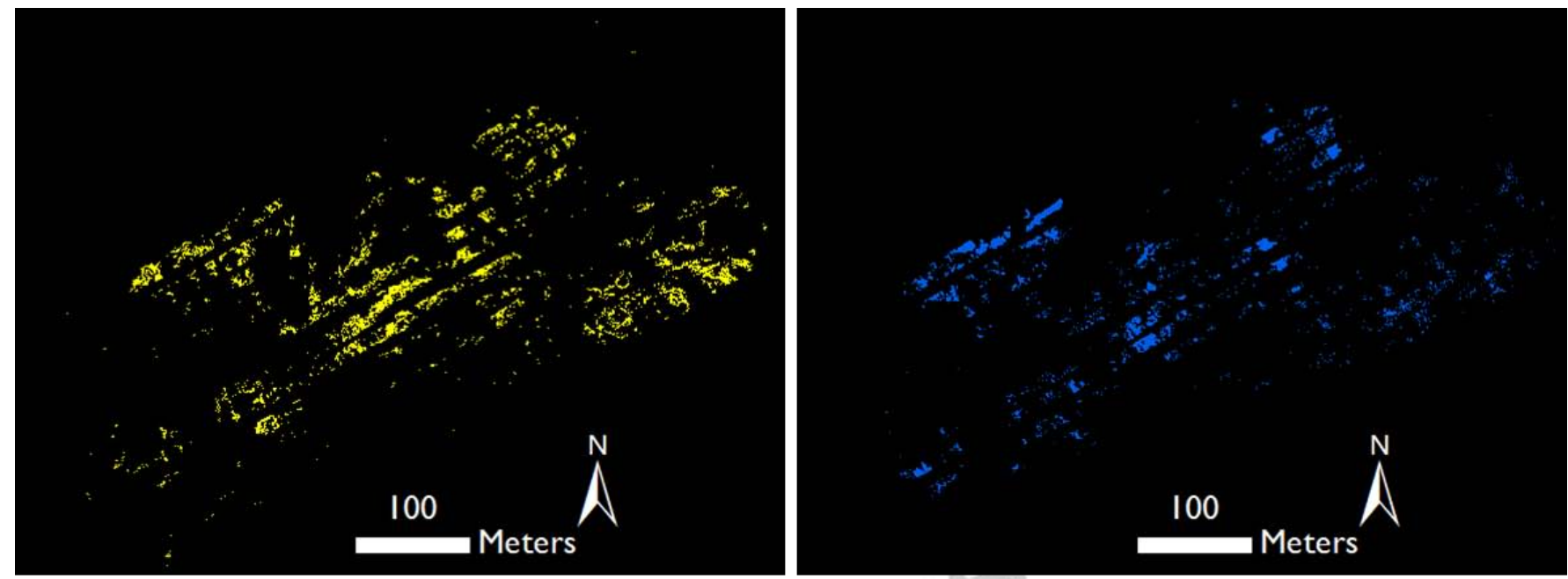

predicted distribution of $E$. southwardae

actual distribution of $E$. southwardae
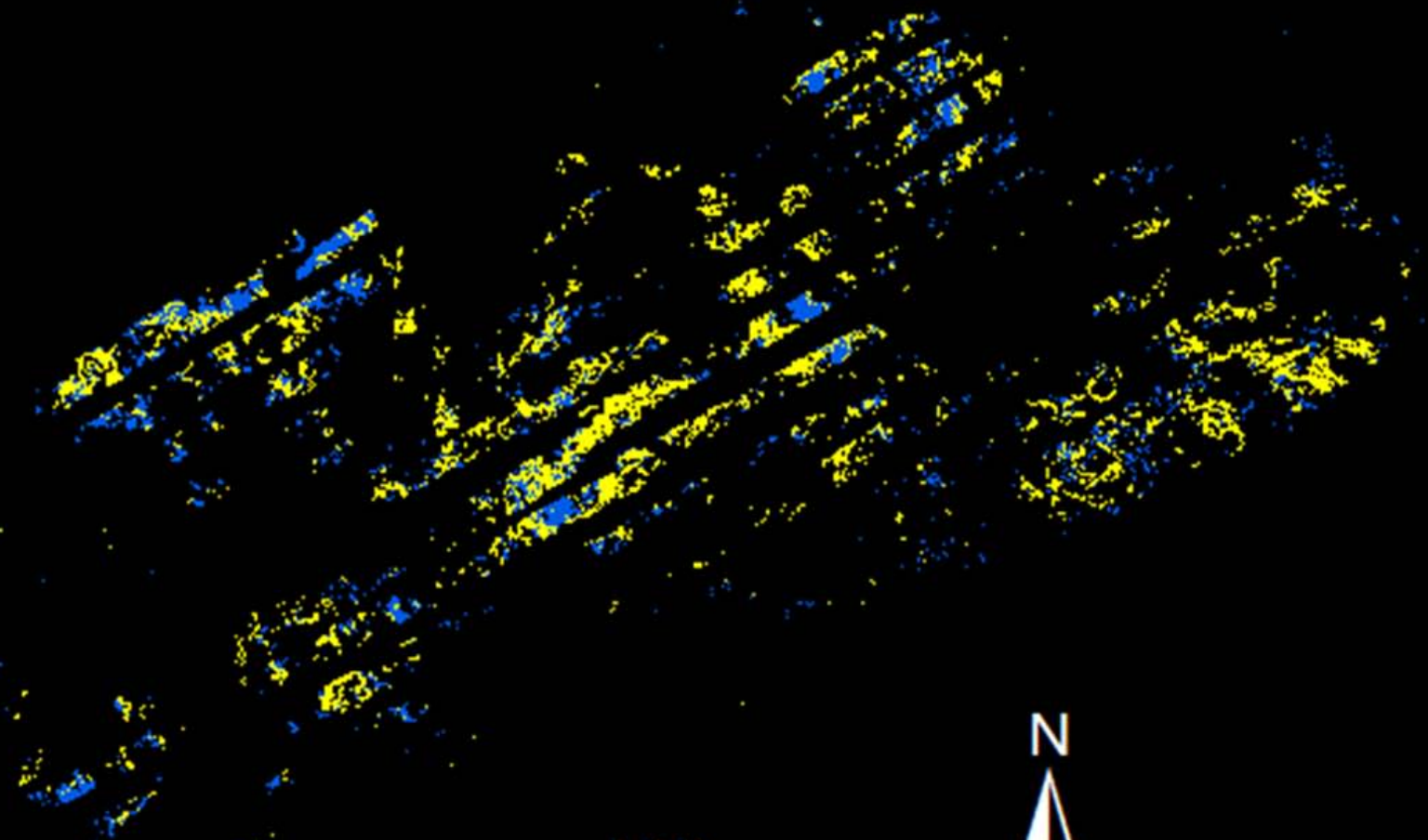

100

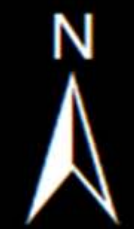

Meters 


\section{ACCEPTED MANUSCRIPT}

Figure 11: Predicted distributions of $E$. southwardae vestimentiferan tubeworms, based on the $8 \mathrm{~m}$

altitude dataset and observed distributions, based on imagery. Predictions presented here are based on the spatial extent of the OTUS photomosaic.
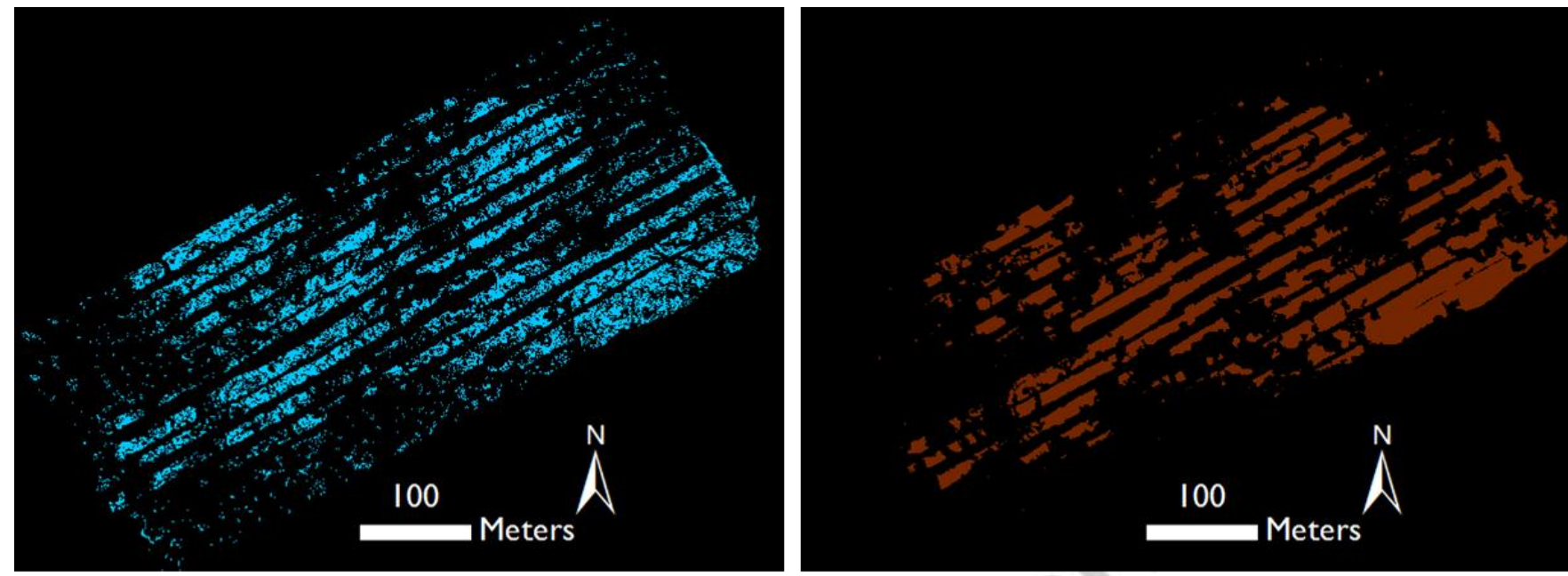

predicted distribution of carbonate

\section{actual distribution of carbonate}

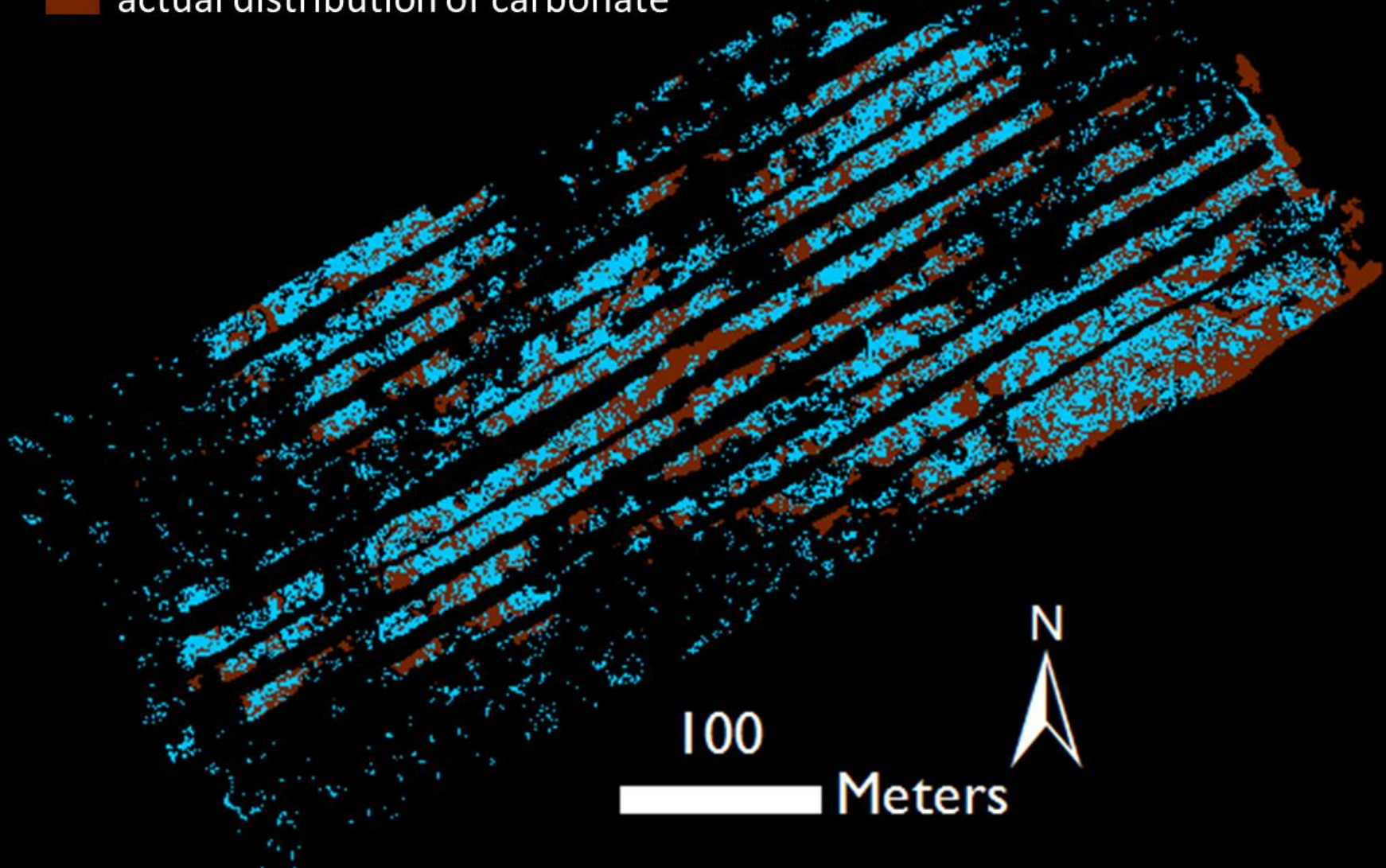




\section{ACCEPTED MANUSCRIPT}

Figure 12: Predicted location of carbonate rock, based on the $8 \mathrm{~m}$ altitude dataset and observed

distributions, based on imagery. Predictions presented here are based on the spatial extent of the OTUS photomosaic.

\begin{tabular}{lcccc}
\hline & \multicolumn{2}{c}{ Predicted Area $\left(\mathrm{m}^{2}\right)$} & \multicolumn{2}{c}{ Observed Area $\left(\mathrm{m}^{2}\right)$} \\
& Total & Percent of OTUS mosaic & Total & Percent of OTUS mosaic \\
\hline $8 \mathrm{~m}$ altitude dataset & & & & \\
E. southwardae & 6520.44 & 6.17 & 4791.16 & 4.51 \\
Carbonate rock & 27730.38 & 26.11 & 34576.07 & 32.56 \\
& & & & \\
$30 \mathrm{~m}$ altitude dataset & & & & \\
E. southwardae & 5789.86 & 5.45 & 4791.16 & 4.51 \\
Vesicomyid clams & 25431.25 & 23.95 & 2979.06 & 2.81 \\
\hline
\end{tabular}

Table 1: Predicted and observed areas of E. southwardae, carbonate rock and vesicomyid clams.

Total areas are displayed and also as a percentage of the OTUS photomosaic.

\begin{tabular}{|c|c|c|c|c|c|}
\hline \multicolumn{2}{|c|}{$8 \mathrm{~m}$ altitude dataset } & \multirow[b]{2}{*}{$\begin{array}{l}\% \text { of } \\
\text { polygons } \\
\text { within } \\
\text { radius }\end{array}$} & \multicolumn{3}{|c|}{$30 \mathrm{~m}$ altitude dataset } \\
\hline Radius & $\begin{array}{l}\text { \# of } \\
\text { polygons } \\
\text { within } \\
\text { radius }\end{array}$ & & Radius & $\begin{array}{l}\text { \# of polygons } \\
\text { within radius }\end{array}$ & $\begin{array}{l}\% \text { of polygons } \\
\text { within radius }\end{array}$ \\
\hline E. southwardae & & & E. southwardae & & \\
\hline $1 \mathrm{~m}$ & 1694 & 60.1 & $1 \mathrm{~m}$ & 1768 & 62.7 \\
\hline $2 \mathrm{~m}$ & 2046 & 72.6 & $2 m$ & 2181 & 77.3 \\
\hline $3 \mathrm{~m}$ & 2296 & 81.4 & $3 \mathrm{~m}$ & 2439 & 86.5 \\
\hline $4 \mathrm{~m}$ & 2440 & 86.5 & $4 \mathrm{~m}$ & 2562 & 90.9 \\
\hline $5 \mathrm{~m}$ & 2532 & 89.8 & $5 \mathrm{~m}$ & 2651 & 94.0 \\
\hline $10 \mathrm{~m}$ & 2736 & 97.0 & $10 m$ & 2785 & 98.8 \\
\hline $20 \mathrm{~m}$ & 2808 & 99.6 & $20 \mathrm{~m}$ & 2816 & 99.9 \\
\hline $25 \mathrm{~m}$ & 2813 & 99.8 & $25 \mathrm{~m}$ & 2820 & 100 \\
\hline Carbonate rock & & & Vesicomyid clams & & \\
\hline $1 \mathrm{~m}$ & 427 & 83.6 & $1 \mathrm{~m}$ & 2140 & 73.0 \\
\hline $2 \mathrm{~m}$ & 467 & 91.4 & $2 \mathrm{~m}$ & 2418 & 82.4 \\
\hline $3 \mathrm{~m}$ & 485 & 94.9 & $3 \mathrm{~m}$ & 2600 & 88.6 \\
\hline $4 \mathrm{~m}$ & 498 & 97.5 & $4 \mathrm{~m}$ & 2717 & 92.6 \\
\hline $5 \mathrm{~m}$ & 502 & 98.2 & $5 \mathrm{~m}$ & 2799 & 95.4 \\
\hline $10 \mathrm{~m}$ & 507 & 99.2 & $10 \mathrm{~m}$ & 2925 & 99.7 \\
\hline $20 \mathrm{~m}$ & 511 & 100 & $20 \mathrm{~m}$ & 2933 & 100 \\
\hline $25 \mathrm{~m}$ & 511 & 100 & $25 \mathrm{~m}$ & 2933 & 100 \\
\hline
\end{tabular}




\section{ACCEPTED MANUSCRIPT}

Table 2: Digitized polygons of real distributions of faunal groups and carbonate within varying distances of predicted polygons. For each habitat/substrate type, the total number of real polygons within set distances of predicted polygons are presented, followed by the percentage of real polygons within set distances of predicted polygons.

The combined raster obtained from data collected at a $30 \mathrm{~m}$ altitude provided reliable predictions of E. southwardae and vesicomyid clams (Figures 14-15). Within the area covered by the OTUS photomosaic, this raster predicted areal coverage by $E$. southwardae to be $5789.86 \mathrm{~m}^{2}$, or, $5.45 \%$ of the OTUS photomosaic and $94 \%$ of the actual tubeworm aggregations were within $5 \mathrm{~m}$ of predicted aggregations (Table 1). This dataset predicted much higher coverage by vesicomyid clams than was observed: $25431.25 \mathrm{~m}^{2}$ (23.95\% of the OTUS photomosaic) was predicted, as opposed to $2979.06 \mathrm{~m}^{2}$ ( $2.8 \%$ of the OTUS photomosaic, Table 1 ) and the possible reasons for this is discussed later. However, the locations of the predictions was quite accurate, with $95 \%$ of all actual aggregations being within $5 \mathrm{~m}$ of predictions (Table 2). 


\section{ACCEPTED MANUSCRIPT}

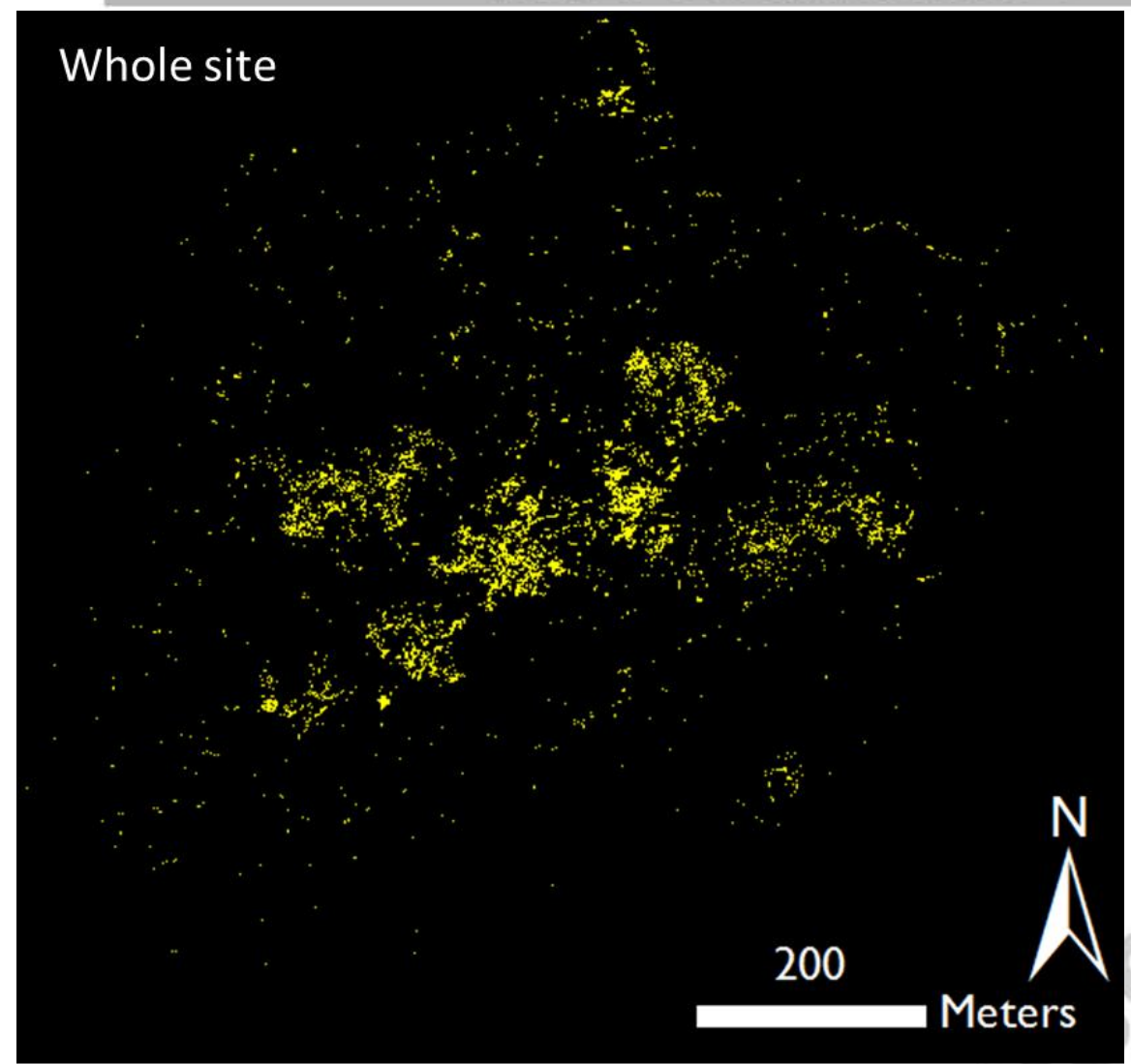

\section{Within OTUS photomosaic}

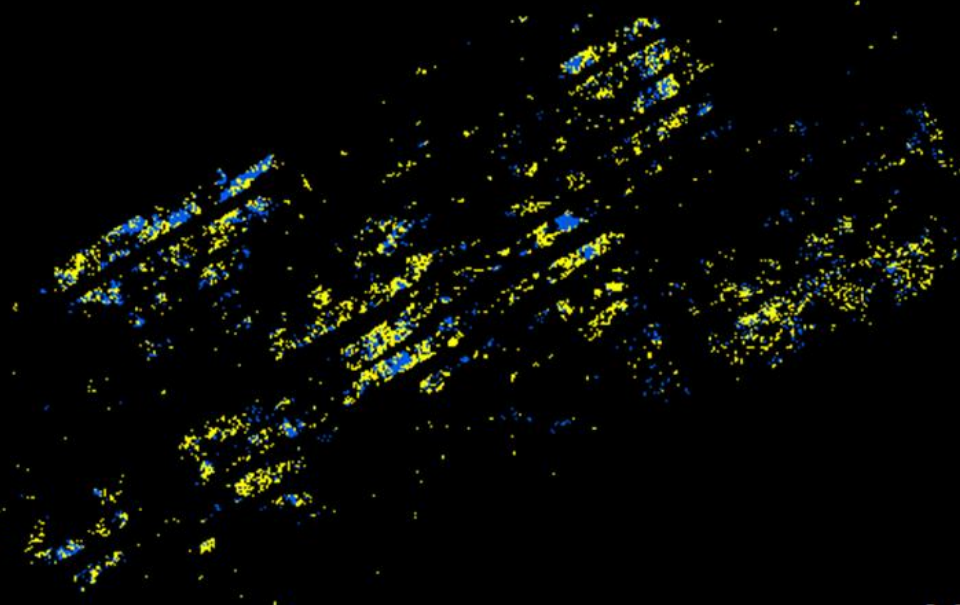

predicted distribution of $E$. southwardae

Figure 13: Predicted distributions of E. southwardae vestimentiferan tubeworms, based on the $30 \mathrm{~m}$ altitude dataset and actual distributions, based on imagery. In the lower panel, only distributions of tubeworms and predictions based on the spatial extent of the OTUS photomosaic is shown. 


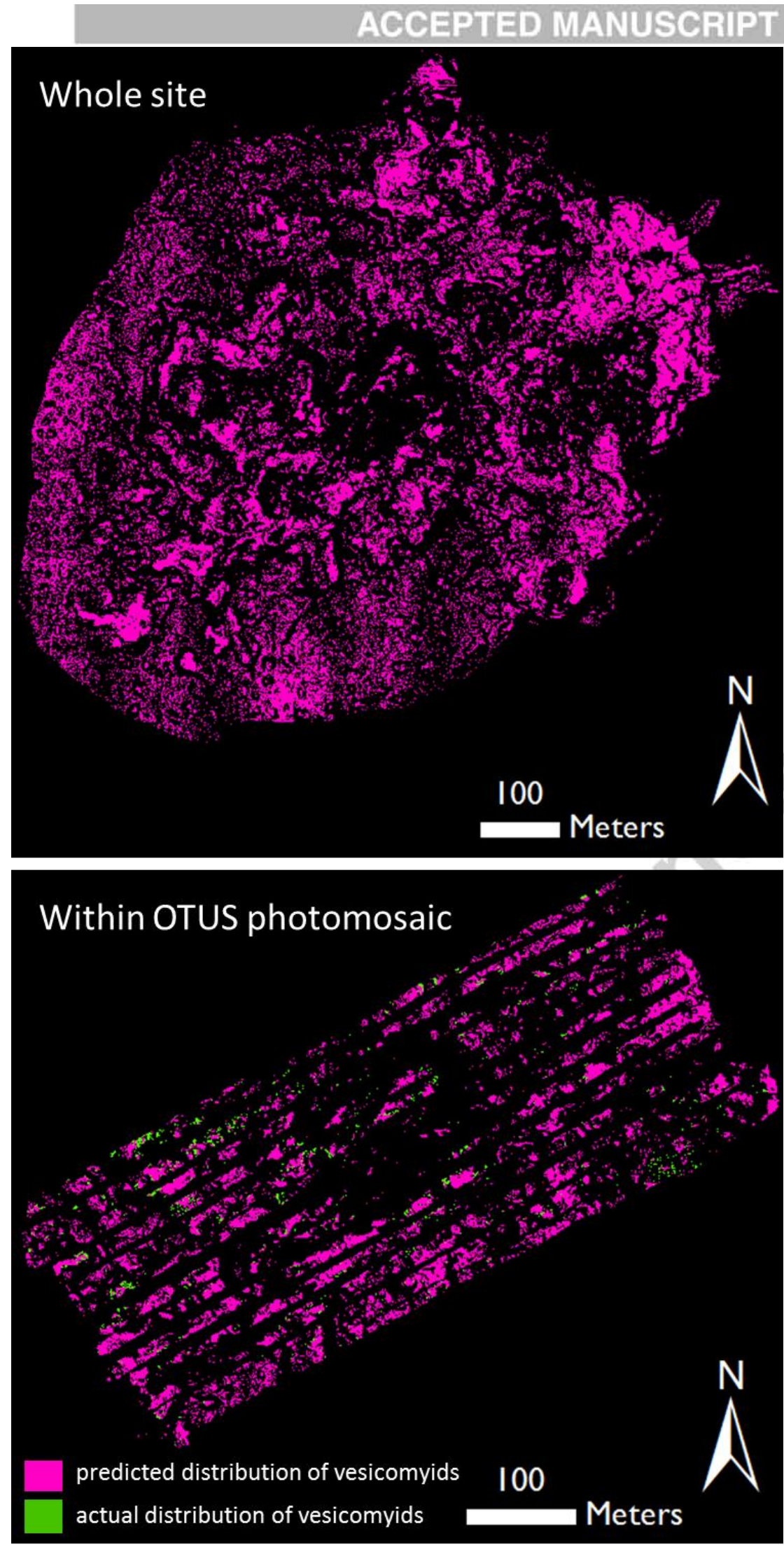

Figure 14: Predicted distributions of vesicomyid clams, based on the $30 \mathrm{~m}$ altitude dataset and actual distributions, based on imagery. In the lower panel, only predictions based on the spatial extent of 


\section{ACCEPTED MANUSCRIPT}

the OTUS photomosaic is shown, since predictions could only be ground truthed based on the photographs.

Since detailed images were not collected for the whole pockmark and the extent of the combined raster obtained from the $30 \mathrm{~m}$ altitude data, not all predictions from this raster could be sufficiently ground truthed. However, in addition to the areas within the OTUS mosaic that contained vesicomyid clams, this raster displayed reliable predictions of clam beds observed from video surveys. For example, the WACS Mosaic 1 area clam bed, described in Olu-Le Roy et al. (2007a) is clearly delineated within the prediction of the distribution of vesicomyid clams (Figure 15). Additionally, the single transect mosaic made from images from dive 429 over other areas of the pockmark revealed the presence of numerous vesicomyid clam clusters that correspond with the predictions made by the combined raster (Supplementary Figure 3). 


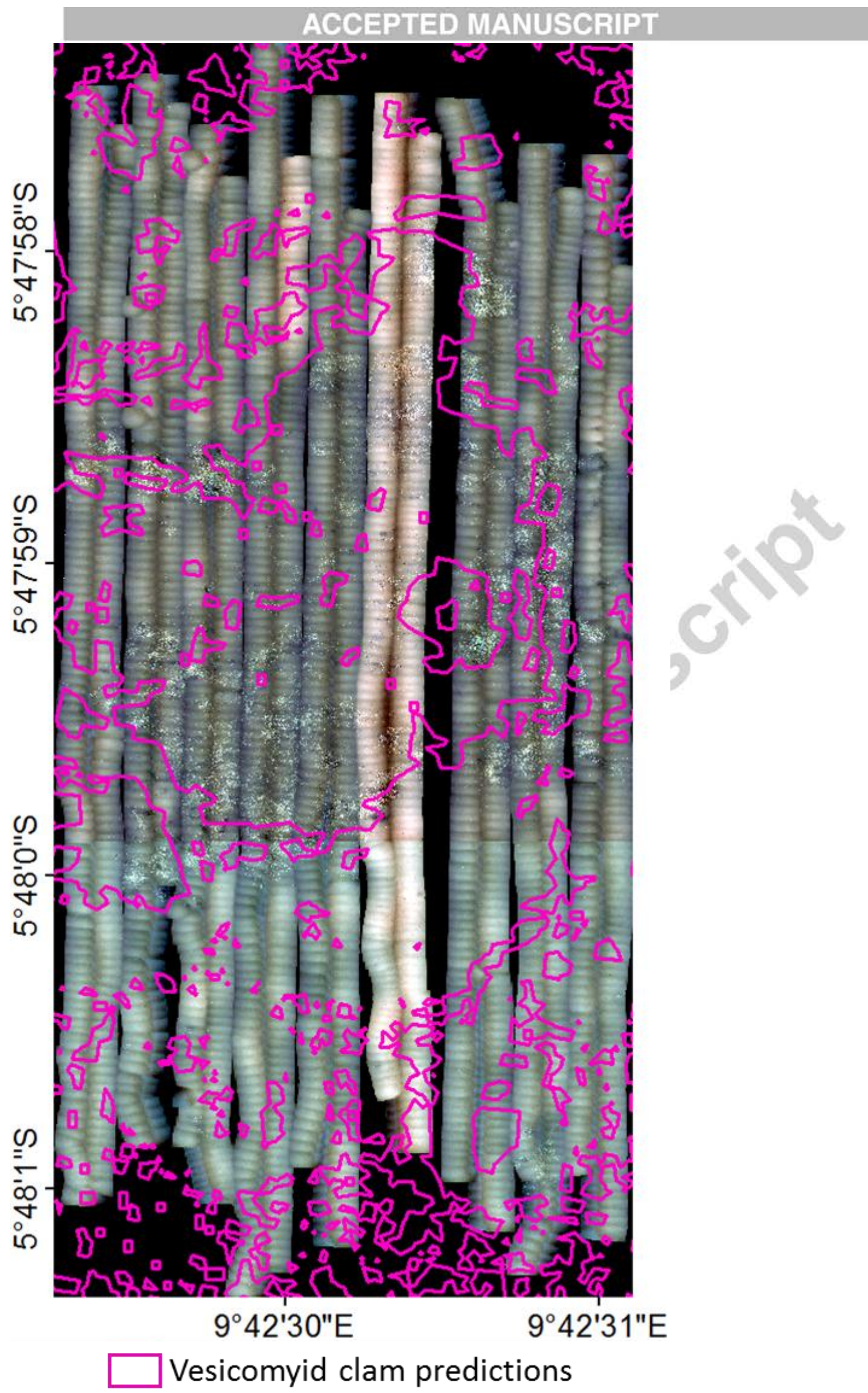

Figure 15: WACS Mosaic 1 with the predictions of vesicomyid clams overlain on it. 
None of the categories obtained through the combined rasters in the method developed here were successful at predicting the distribution of the mussel, $B$. aff. boomerang.

\section{Discussion}

The deep sea is highly diverse and hosts unique, but threatened ecosystems that hold promise for understanding the origin of life, and is home to a number of unknown species. Mapping distributions of both the fauna and habitats of these systems is an essential first step required if effective conservation strategies are to be developed or sustainable exploitation of these systems is to take place. Additionally, since habitat heterogeneity is linked to biodiversity, habitat mapping can be used as a proxy for estimating and assessing faunal diversity (Cordes et al., 2010). Technological advances have greatly enhanced our ability to map large swathes of the seafloor and industries have been quick to capitalize on this capability (Berkes et al., 2006; Davies et al., 2007). However, the output of many mapping techniques is restricted to visualizations of abiotic features such as topography or substrate and sediment types, that provide a limited understanding of species distributions (Kostylev et al., 2001; Moustier, 1986). Therefore, there is a need to develop techniques that are capable of mapping biological communities in addition to abiotic features of the deep seafloor. We report here a procedure that incorporates fairly easily obtainable datasets acquired completely non-invasively through a multibeam echosounder mounted on an ROV for precisely this function in a cold seep habitat located at a depth of over $3000 \mathrm{~m}$. Two datasets obtained at two different altitudes were used and compared for their ability to predict habitat distribution.

Our developed method successfully predicts the distribution of carbonate rock, vestimentiferan tubeworms and vesicomyid clams, but was incapable of predicting the distribution of mytilid mussels. The predictions did not overlap $100 \%$ with observed distributions. However, they provided a reliable estimate of the general location of the presence of carbonate, tubeworms and vesicomyids, that are accurate within $5 \mathrm{~m}$ with at least $90 \%$ confidence. The precision of the predictions made by the $30 \mathrm{~m}$ 


\section{ACCEPTED MANUSCRIPT}

altitude dataset were more likely to be affected due to navigational offsets because multibeam data and images for ground truthing were collected during different dives and georeferenced based on different navigational files. However, in the one case where a category could be predicted by both the $8 \mathrm{~m}$ and the $30 \mathrm{~m}$ altitude datasets, (the vestimentiferan tubeworm E. southwardae), the predictions made by the $30 \mathrm{~m}$ altitude dataset were in fact, more precise than those made by the $8 \mathrm{~m}$ altitude dataset, both in terms of the total areal cover of this species $\left(5789 \mathrm{~m}^{2}\right.$ predicted by the $30 \mathrm{~m}$ altitude dataset, $6520 \mathrm{~m}^{2}$ predicted by the $8 \mathrm{~m}$ altitude dataset as opposed to an observed coverage of $4791 \mathrm{~m}^{2}$ ), as well as in terms of the accuracy of the locations of the predictions ( $94 \%$ of predictions within $5 \mathrm{~m}$ of observed locations for the $30 \mathrm{~m}$ altitude dataset as opposed to $89.8 \%$ within $5 \mathrm{~m}$ of observed locations for the $8 \mathrm{~m}$ altitude dataset). It is possible that the result of the $30 \mathrm{~m}$ altitude dataset being more accurate than the $8 \mathrm{~m}$ altitude dataset is due to pure chance alone. However, given the size of the datasets, the large numbers of predictions made and the extensive areas covered, this seems unlikely and suggests that navigational offsets between dives were very low. It should be kept in mind that the overall accuracy of the method could have been affected by human error, since the digitization of the faunal groups and carbonate structures was conducted manually and therefore involved a certain degree of subjectivity. Nonetheless, generally speaking, the method does successfully and accurately predict substrates and faunal assemblages. To put our results into perspective, the predictions obtained from this method are as accurate, and in some instances, more accurate than GPS on modern day smartphones (Zandbergen, 2009; Zandbergen and Barbeau, 2011). Therefore this study represents a very important and useful step towards semiautomated large scale mapping of deep-sea systems such as cold seeps.

\section{Distribution of tubeworms}

Vestimentiferan tubeworms were predicted successfully by both datasets, obtained from the two different altitudes. Since vestimentiferan tubeworms need a hard substrate to settle on, their distribution overlaps considerably with that of carbonate rock. However, the method could 


\section{ACCEPTED MANUSCRIPT}

distinguish between the two and made accurate predictions of tubeworms even within predictions of

carbonate. A comparison between the predictions of tubeworms and the original backscatter map revealed that the backscatter alone can be used for predicting tubeworm distributions to a certain extent: they tend to be located in areas where high reflectivity is interspersed with areas of low reflectivity. However, the range of values constituting high and low reflectivity varied considerably, which made it impossible to use the backscatter alone to automatically or semi-automatically predict tubeworm distributions with any degree of reliability. Furthermore, even areas with high reflectivity signals displayed some variability in exact values, making it unreliable to predict tubeworm distributions by even manually marking areas of low reflectivity amidst areas of high reflectivity from the backscatter data alone. Therefore, this method, combining backscatter and bathymetry, improves on the data contained within backscatter maps for visualizing the distribution of vestimentiferans on the seafloor.

A visual comparison between the dataset obtained from an altitude of $30 \mathrm{~m}$ and the dataset obtained from an altitude of $8 \mathrm{~m}$ revealed that the predictions from the two different datasets were very similar. However, as mentioned earlier, the $30 \mathrm{~m}$ altitude dataset was more accurate, both in terms of the amount of area predicted to constitute tubeworms, as well as in terms of the proximity of predicted tubeworms assemblages to real tubeworm aggregations. Both datasets overestimated the total tubeworm coverage seen in the OTUS photomosaic, however, the total tubeworm coverage predicted by the $30 \mathrm{~m}$ altitude dataset $\left(5789.56 \mathrm{~m}^{2}\right)$ was more similar to the actual extent of tubeworm coverage $\left(4791.16 \mathrm{~m}^{2}\right)$ than what was predicted by the $8 \mathrm{~m}$ altitude dataset $\left(6520.44 \mathrm{~m}^{2}\right)$. Tubeworms extend up to a few meters above the seafloor, thereby creating localized relief patterns. Additionally, they are found on carbonate rocks, which can also create relief on the seafloor. Since the method described here incorporates bathymetry data, it is possible that at the lower altitude and with higher resolution bathymetry mapping, small scale topographical highs were detected more frequently and resembled the relief created by tubeworms and/or their underlying carbonate 


\section{ACCEPTED MANUSCRIPT}

strongholds. This could explain why more extensive predictions of tubeworm habitat were made by the lower altitude dataset.

Nonetheless, both datasets were quite accurate at predicting tubeworm aggregations. More than $70 \%$ of all tubeworm aggregations were within $2 \mathrm{~m}$ of predicted aggregations (for both datasets). The only clusters of tubeworms completely missed by the method and far removed from predictions were small aggregations, consisting of only a few individuals. Surprisingly, the $8 \mathrm{~m}$ altitude dataset was not better at predicting these small, isolated tubeworm patches than the higher altitude dataset. Therefore, finer scale bathymetry and backscatter are not necessarily better or even sufficient for detecting the presence of small, remote clumps or solitary individuals of tubeworms. Most of the tubeworms outside a $5 \mathrm{~m}$ radius of predictions were recumbent or juvenile tubeworm aggregations. The smaller size of the juveniles and the lower height of the individuals in a recumbent posture could contribute towards the difficulty of detecting these assemblages through the method described here. It should be noted that not all recumbent or juvenile aggregations are missed by the method. Only a small number of very minute sized aggregations could not be predicted.

\section{Carbonate prediction}

Carbonate could only be predicted with the $8 \mathrm{~m}$ altitude dataset. Though the prediction of carbonate rarely missed any region where carbonate was present, it appears to also predict carbonates where none was observed. Undoubtedly some of these extra predictions are truly false positives, however, it is also likely that a number of the seemingly incorrect predictions are in fact accurate and carbonate structures were simply not visible in the photographs of those regions, because they are under the animals or a layer of sediment. For example, there are areas where tubeworms were visible and marked from optical images, but carbonate was not seen or marked in the same area. This case is illustrated in Figure 16, which shows an area where tubeworms were seen and marked but carbonate was not, although it is very likely present under the tubeworms. Our method predicted the presence of carbonate in this location. 


\section{ACCEPTED MANUSCRIPT}

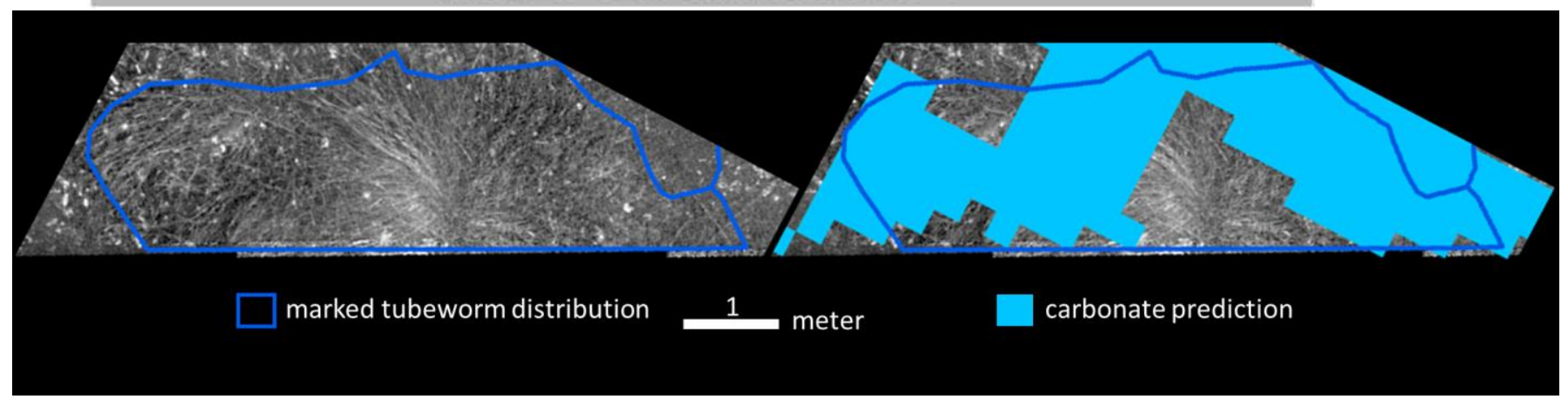

Figure 16: Areas where tubeworms were seen, but carbonate was not visible. On the left is an example of an area where tubeworms were visible and marked, but no carbonate was seen. On the right is the same area, with the prediction of carbonate.

Tubeworms require a hard substrate to settle on (Sigvaldadottir et al., 2003; Southward, 2000;

Southward et al., 2005) and the composition of cold seeps including Regab is mainly soft sediment.

The only exception is the hard substrate of biologically produced carbonate rock (Aloisi et al., 2002;

Pierre and Fouquet, 2007) that is present in most of the central part of the Regab pockmark

(Ondreas et al.2005 Marcon et al., 2014, 2013a; Olu-Le Roy et al., 2007a). Therefore tubeworms

cannot theoretically be present where carbonate is not. In a similar way, mussels are also often

located on carbonate and most of the mussels at Regab are located on or near carbonate structures

(Olu-Le Roy et al., 2007a). Furthermore, shells, debris or sedimentation can similarly mask the

presence of underlying carbonate rock. Therefore it is likely that a number of the seemingly

inaccurate predictions of carbonate are in fact correct, but it is impossible to verify this with the available data.

On the other hand, total carbonate predictions overall fell short of the actual area constituting carbonate. It appears that the method does not predict very large carbonate structures. Multiple predictions of smaller structures were often predicted in places where a very large carbonate structure exists in reality. The largest carbonate rock seen in the OTUS photomosaic measures about $5646 \mathrm{~m}^{2}$ but the largest predicted structure is only about $832 \mathrm{~m}^{2}$ in size. However, despite the underestimation of coverage, the total prediction is not too far off the mark in terms of estimations 


\section{ACCEPTED MANUSCRIPT}

of areas of carbonate coverage: 27730.30 square meters of carbonate structure was predicted and 34576.07 square meters was observed (80\%). Furthermore, it is very accurate; about $91 \%$ of all existing carbonate structures were within $2 \mathrm{~m}$ of predicted structures.

\section{Vesicomyid clam prediction}

Vesicomyid clams could also only be predicted by one of the datasets, but unlike carbonate, the $30 \mathrm{~m}$ altitude dataset was the one capable of making these predictions. Marcon et al. (2013a) found that the small points of high reflectivity all over the pockmark seen in the backscatter map of Regab were clusters of either dead or living vesicomyid clams. Therefore, backscatter alone can reveal the presence of vesicomyids in the pockmark. However, it is simply a high reflectivity signal and the scattered clam clusters stand out easily among large areas of sediment that exhibit a low reflectivity signal, but that is not sufficient for predicting clam distributions among other substrates that also produce high reflectivity signals. For this purpose, the method described here is much more useful for estimating the presence of clams, than simple backscatter maps alone. While the method described here does not miss any actual clam aggregations, and is quite accurate in the locations of its predictions, it does predict much higher coverage than is visible through the imagery. A reason for the overestimation of vesicomyids could be related to the resolution of the backscatter map (in this study: $5 \times 5 \mathrm{~cm}^{2}$ for the $8 \mathrm{~m}$ survey and $10 \times 10 \mathrm{~cm}^{2}$ for the $30 \mathrm{~m}$ survey). Indeed, the backscatter intensity of a grid cell corresponds to the average backscatter of the area on the seafloor that is represented within this cell. This means that even if only a small fraction of that area is occupied by a hard substrate (e.g. clam shells), the overall average backscatter value of that grid cell area will be high in comparison to that of a cell with only soft sediments. In such a case, the resulting elevated backscatter value is applied to the entire cell area, which is larger than the area that is actually occupied by clam shells. Although such overestimation error is likely to be negligible in the case of large assemblages, we expect that it can be quite significant for the smaller assemblages. In contrast to the other faunal assemblages, a large part of the vesicomyid population is distributed in numerous 


\section{ACCEPTED MANUSCRIPT}

tiny aggregates with very few individuals (this study and Marcon et al., 2013a). We expect that the total size overestimation over all those aggregates account for part of the overestimation error we observe in the predicted clam population. This also explains why the clam population is more overestimated than the other faunal types.

Additionally, vesicomyid clams tend to burrow into soft sediment and use a muscular foot to take up hydrogen sulfide from the sediment (Scott and Fisher, 1995). Often only a small portion of their shells are visible above the sediment and in some cases, only their protruding siphons are visible. Both species found at Regab can burrow, and particularly, Laubiericoncha chuni, due to its long siphons (Krylova \& Cosel 2011). It is also assumed that the extremely high oxygen affinity of this species allows it to dig deeper in the sediment and remain buried longer than other vesicomyid species (Decker et al., 2014). Only siphons of this species are visible at times, which can be missed on optical images. Therefore, it is possible that more vesicomyid clams are present in Regab than can be seen and marked through imagery, which could account for some of the predictions made by this method. Photographic images were obtained from an altitude of $8 \mathrm{~m}$, which is still relatively high, and small animals only a few centimeters across are not always visible from this height. Mostly buried clams would also not be very visible in such images. The reflectivity signals of vesicomyid clams that constitute the backscatter data used for this method are based off the hard shells of the clams and not the soft bodies. Therefore, it is also possible that buried shells could also contribute towards some of the unconfirmed clam predictions. The frequency of the echosounder was $400 \mathrm{kHz}$, with an approximate wavelength of $5 \mathrm{~mm}$. Power was sacrificed for high frequency and the waves likely only penetrated a few centimeters below the surface. However, even a fine layer of sediment only a few centimeters thick would be enough to cover clams (particularly dead individuals) and make them invisible in photographs. Therefore, the population of both dead and living individuals of vesicomyid clams could exceed what was seen and marked in the photomosaic, and could contribute towards some of the predictions of clams that did not correspond with visible clam aggregations. 


\section{ACCEPTED MANUSCRIPT}

Recommendations, advantages and limitations of the method

The variable results of the two datasets obtained from two altitudes indicate that the height from which backscatter and bathymetry is obtained plays a significant role in the types of substrates or fauna that can be predicted. Carbonate could not be predicted from the higher altitude dataset and vesicomyid clams could not be accurately predicted from the lower altitude dataset. The two datasets were obtained from altitudes more than $20 \mathrm{~m}$ apart. This suggests that an intermediate altitude could be more optimal and provide the combined results of the two datasets used here. However, such exploratory studies would require a great deal of time and effort and would have to follow the model of the $8 \mathrm{~m}$ altitude dataset, where both multibeam data and imagery were acquired simultaneously, for it to be possible to test the accuracy of the predictions obtained from the various altitudes. A major limitation of this study is that the method described could not distinguish between dead or senescent aggregations from healthy, living individuals. This is likely mainly due to the backscatter signals being a product of the reflective properties of shells and tubes as opposed to soft body tissue. The types of tubeworm aggregations most often missed by the method tended to be very small clusters of either juvenile or recumbent individuals. These aggregations have one important feature in common: limited vertical height. Since the method uses derivatives of bathymetry, the relatively low vertical relief associated with both young individuals of tubeworms and those in a recumbent posture might account not only for the inability of the method to identify small aggregations of juveniles and senescent tubeworms, but also for the inability of the method to distinguish between living, but young individuals, from dying or dead individuals. Therefore, it appears that optical imagery is still the best option for delineating aggregations of live animals and differentiating them from dead or dying individuals. Additionally, this method cannot be used for estimating biomass. It provides useful and reliable estimates of the locations of various faunal groups, as well as the sizes of aggregations, but it provides no data on the densities of individuals. Therefore, for studies aiming to quantify biomass or numbers of individuals of the different faunal groups, optical imagery is necessary. 


\section{ACCEPTED MANUSCRIPT}

The other main limitation is that the distribution of mussels could not be predicted by this method.

Mytilid mussels are ubiquitous in the world's oceans and the sub-family Bathymodiolinae is a

common taxon found at reducing environments such as cold seeps, wood falls and hydrothermal

vents (Duperron et al., 2009; Miyazaki et al., 2010). Therefore it is important to be able to map their

distributions. They appear to prefer carbonate structures over soft sediment and often form mixed aggregations with tubeworms (Hecker, 1985; MacDonald et al., 1990a, 1990b, 1989; Marcon et al., 2014; Olu-Le Roy et al., 2007a). One reason that could account for the inability of the method described here to predict their distribution is their overlap with the other major categories being investigated such as carbonate rock and vestimentiferan tubeworms. In regions of the world where mytilid mussels cover very large areas, forming literal fields of mussels, it might be possible for this method to accurately predict their distribution. At Regab, mussels do form large aggregations, but they coincide with either carbonate or tubeworms and this could be a reason why we were unable to map their locations through the developed method. Since we did not have access to backscatter and bathymetry maps of regions such as the Brine Pool in the Gulf of Mexico where mussel fields are present (MacDonald et al., 1990a, 1989; Smith et al., 2000) , we could not test whether this method would be able to predict vast mussel fields. The method described here could benefit by applying it to such regions.

However, it is worth noting that all mussel aggregations were located in areas predicted to be either carbonate or tubeworms (Figure 17). Therefore, at the scale of the pockmark, we were able to distinguish between areas where mussels could possibly be located and where mussels were not present at all. This is useful from the perspective of being able to differentiate between the biota and uninhabited substrate. However, the method needs to be refined and applied to different geographic regions in order to accurately predict the distribution of mytilid mussels and separate them from other predictions of substrate or fauna. 


\section{ACCEPTED MANUSCRIPT}
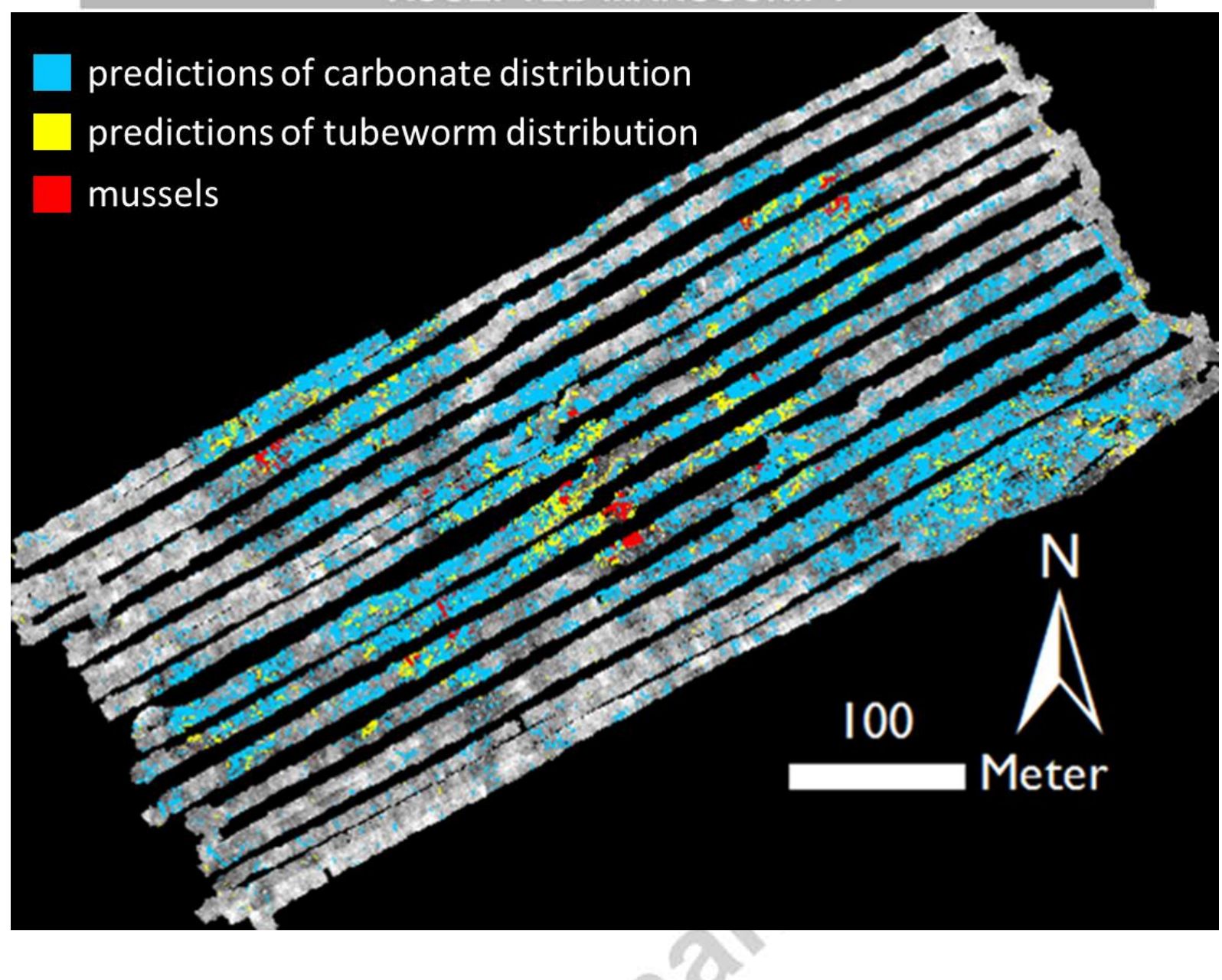

Figure 17: Distribution of the mytilid mussel, Bathymodiolus aff. boomerang and the predictions of tubeworm and carbonate distributions. Note that mussel distributions fall within the predicted distributions of tubeworms and carbonate

The major advantage of this method is that it is mostly automated. A few steps do require operator input and is subject to a certain amount of subjectivity, such as choosing the point of inflection from the values of the slope gradient map for classifying the bathymetry map into flat or sloping, choosing the values to determine smooth and rough areas and the value by which to further segment the two backscatter datasets. These choices were made based on the distribution of values and operators employing this method should have some knowledge of the ecosystem being studied and a basic understanding of statistics. 


\section{ACCEPTED MANUSCRIPT}

In conclusion, we have developed a method by which the major substrate types and faunal assemblages of a cold seep site could be mapped fairly quickly and easily. Backscatter and bathymetry data form the backbone of the method, and these data can be obtained in a fraction of the time needed to obtain detailed optical images. The method could be enhanced by testing it in different geographical regions and different altitudes above the seafloor, but is still very useful in making accurate predictions in its current form. As interest in the deep sea increases, we expect our approach to be able to provide an efficient and cost-effective means by which to map dominant faunal assemblages and substrate types, thereby providing the information needed to effectively manage the diverse resources of the deep sea.

Acknowledgements

We are very grateful to the crews of the R/V Pourquoi Pas? and Victor 6000 , without whom data collection would not have taken place. We are also thankful to Aurélien Arnaubec for developing Matisse version 3 and training the authors in its use. We thank Sebastien Rochette, who introduced us to the Micallef et al. 2012 study and also, Aaron Micallef, who was very helpful in explaining details of his method. Funding for this project was provided by Ifremer and Institut Carnot Edrome.

\section{References}

Aloisi, G., Bouloubassi, I., Heijs, S.K., Pancost, R.D., Pierre, C., Damsté, J.S.S., Gottschal, J.C., Forney, L.J., Rouchy, J.-M., 2002. CH 4-consuming microorganisms and the formation of carbonate crusts at cold seeps. Earth Planet. Sci. Lett. 203, 195-203.

Andersen, A.C., Hourdez, S., Marie, B., Jollivet, D., Lallier, F.H., Sibuet, M., 2004. Escarpia southwardae sp. nov., a new species of vestimentiferan tubeworm (Annelida, Siboglinidae) from West African cold seeps. Can. J. Zool. 82, 980-999. doi:10.1139/z04-049

Baker, M., German, C., 2009. Going for Gold! Who will win the race to exploit ores from the deep? Ocean Chall. 16, 10-17. 


\section{ACCEPTED MANUSCRIPT}

Beaman, R.J., Daniell, J.J., Harris, P.T., 2005. Geology-benthos relationships on a temperate rocky bank, eastern Bass Strait, Australia. Mar. Freshw. Res. 56, 943-958.

Berkes, F., Hughes, T.P., Steneck, R.S., Wilson, J.A., Bellwood, D.R., Crona, B., Folke, C., Gunderson, L.H., Leslie, H.M., Norberg, J., Nyström, M., Olsson, P., Österblom, H., Scheffer, M., Worm, B., 2006. Globalization, roving bandits, and marine resources. Science 311, 1557-1558. doi:10.1126/science.1122804

Brown, C.J., Smith, S.J., Lawton, P., Anderson, J.T., 2011a. Benthic habitat mapping: A review of progress towards improved understanding of the spatial ecology of the seafloor using acoustic techniques. Estuar. Coast. Shelf Sci. 92, 502-520. doi:10.1016/j.ecss.2011.02.007

Brown, C.J., Todd, B.J., Kostylev, V.E., Pickrill, R.A., 2011b. Image-based classification of multibeam sonar backscatter data for objective surficial sediment mapping of Georges Bank, Canada. Cont. Shelf Res., Geological and Biological Mapping and Characterisation of Benthic Marine Environments 31, S110-S119. doi:10.1016/j.csr.2010.02.009

Callaway, A., Smyth, J., Brown, C.J., Quinn, R., Service, M., Long, D., 2009. The impact of scour processes on a smothered reef system in the Irish Sea. Estuar. Coast. Shelf Sci., Marine Science in the Western Indian Ocean Responds to Population Pressures and Climate Change 84, 409-418. doi:10.1016/j.ecss.2009.07.011

Cambon-Bonavita, M.A., Nadalig, T., Roussel, E., Delage, E., Duperron, S., Caprais, J.C., Boetius, A., Sibuet, M., 2009. Diversity and distribution of methane-oxidizing microbial communities associated with different faunal assemblages in a giant pockmark of the Gabon continental margin. Deep Sea Res. Part II Top. Stud. Oceanogr., Deep-Sea Benthic Ecosystems of the Equatorial African Margin: The Multidisciplinary BIOZAIRE Program A Contribution to Census of Marine Life 56, 2248-2258. doi:10.1016/j.dsr2.2009.04.007

Charlou, J.L., Donval, J.P., Fouquet, Y., Ondreas, H., Knoery, J., Cochonat, P., Levaché, D., Poirier, Y., Jean-Baptiste, P., Fourré, E., Chazallon, B., 2004. Physical and chemical characterization of gas hydrates and associated methane plumes in the Congo-Angola Basin. Chem. Geol., 


\section{ACCEPTED MANUSCRIPT}

Geomicrobiology and Biogeochemistry of Gas Hydrates and Hydrocarbon Seeps 205, 405425. doi:10.1016/j.chemgeo.2003.12.033

Collier, J.S., Brown, C.J., 2005. Correlation of sidescan backscatter with grain size distribution of surficial seabed sediments. Mar. Geol. 214, 431-449. doi:10.1016/j.margeo.2004.11.011

Conway, K.W., Barrie, J.V., Krautter, M., 2005. Geomorphology of unique reefs on the western Canadian shelf: sponge reefs mapped by multibeam bathymetry. Geo-Mar. Lett. 25, 205-213. doi:10.1007/s00367-004-0204-z

Cordes, E.E., Cunha, M.R., Galéron, J., Mora, C., Olu-Le Roy, K., Sibuet, M., Van Gaever, S., Vanreusel, A., Levin, L.A., 2010. The influence of geological, geochemical, and biogenic habitat heterogeneity on seep biodiversity: Seep habitat heterogeneity. Mar. Ecol. 31, 51-65. doi:10.1111/j.1439-0485.2009.00334.x

Davies, A.J., Roberts, J.M., Hall-Spencer, J., 2007. Preserving deep-sea natural heritage: Emerging issues in offshore conservation and management. Biol. Conserv. 138, 299-312. doi:10.1016/j.biocon.2007.05.011

Decker, C., Zorn, N., Potier, N., Leize-Wagner, E., Lallier, F.H., Olu, Andersen, A.C., 2014. Globin's structure and function in vesicomyid bivalves from the Gulf of Guinea cold seeps as an adaptation to life in reduced sediments. Physiol. Biochem. Zool. 87, 855-869. doi:10.1086/678131

De Falco, G., Tonielli, R., Di Martino, G., Innangi, S., Simeone, S., Michael Parnum, I., 2010. Relationships between multibeam backscatter, sediment grain size and Posidonia oceanica seagrass distribution. Cont. Shelf Res. 30, 1941-1950. doi:10.1016/j.csr.2010.09.006

Duperron, S., Lorion, J., Samadi, S., Gros, O., Gaill, F., 2009. Symbioses between deep-sea mussels (Mytilidae: Bathymodiolinae) and chemosynthetic bacteria: diversity, function and evolution. C. R. Biol., La théorie de Darwin revisitée par la biologie d'aujourd'hui / Darwin's theory revisited by today's biology 332, 298-310. doi:10.1016/j.crvi.2008.08.003 


\section{ACCEPTED MANUSCRIPT}

Duperron, S., Nadalig, T., Caprais, J.-C., Sibuet, M., Fiala-Médioni, A., Amann, R., Dubilier, N., 2005. Dual Symbiosis in a Bathymodiolus sp. mussel from a methane seep on the Gabon Continental Margin (Southeast Atlantic): 16S rRNA phylogeny and distribution of the symbionts in gills. Appl. Environ. Microbiol. 71, 1694-1700. doi:10.1128/AEM.71.4.16941700.2005

Durand, S., Le Bel, M., Juniper, S.K., Legendre, P., 2002. The use of video surveys, a Geographic Information System and sonar backscatter data to study faunal community dynamics at Juan de Fuca Ridge hydrothermal vents. Cah. Biol. Mar. 43, 235-240.

Durand, S., Legendre, P., Juniper, S.K., 2006. Sonar backscatter differentiation of dominant macrohabitat types in a hydrothermal vent field. Ecol. Appl. Publ. Ecol. Soc. Am. 16, 14211435.

Edwards, B.D., Dartnell, P., Chezar, H., 2003. Characterizing benthic substrates of Santa Monica Bay with seafloor photography and multibeam sonar imagery. Mar. Environ. Res., Integrated Assessment of an Urban Water Body: Santa Monica Bay, California 56, 47-66. doi:10.1016/S0141-1136(02)00324-0

Ehrhold, A., Hamon, D., Guillaumont, B., 2006. The REBENT monitoring network, a spatially integrated, acoustic approach to surveying nearshore macrobenthic habitats: application to the Bay of Concarneau (South Brittany, France). ICES J. Mar. Sci. 63, 1604-1615. doi:10.1016/j.icesjms.2006.06.010

Ferrini, V.L., Flood, R.D., 2006. The effects of fine-scale surface roughness and grain size on $300 \mathrm{kHz}$ multibeam backscatter intensity in sandy marine sedimentary environments. Mar. Geol. 228, 153-172. doi:10.1016/j.margeo.2005.11.010

Fisher, C.R., Cordes, E.E., Roberts, H.H., Bernard, B., 2007. Cold seeps and associated communities. Oceanography 20, 118.

Gardner, J.V., Calder, B.R., Hughes Clarke, J.E., Mayer, L.A., Elston, G., Rzhanov, Y., 2007. Drowned shelf-edge deltas, barrier islands and related features along the outer continental shelf north 


\section{ACCEPTED MANUSCRIPT}

of the head of De Soto Canyon, NE Gulf of Mexico. Geomorphology 89, 370-390.

doi:10.1016/j.geomorph.2007.01.005

Gay, A., Lopez, M., Ondreas, H., Charlou, J.-L., Sermondadaz, G., Cochonat, P., 2006. Seafloor facies related to upward methane flux within a Giant Pockmark of the Lower Congo Basin. Mar. Geol. 226, 81-95. doi:10.1016/j.margeo.2005.09.011

Glover, A.G., Gooday, A.J., Bailey, D.M., Billett, D.S.M., Chevaldonné, P., Colaco, A., Copley, J., Cuvelier, D., Desbruyeres, D., Kalogeropoulou, V., 2010. Temporal change in deep-sea benthic ecosystems: a review of the evidence from recent time-series studies. Adv. Mar. Biol. Vol $5858,1-95$.

Goff, J.A., Olson, H.C., Duncan, C.S., 2000. Correlation of side-scan backscatter intensity with grainsize distribution of shelf sediments, New Jersey margin. Geo-Mar. Lett. 20, 43-49. doi:10.1007/s003670000032

Halfar, J., Fujita, R.M., 2007. Ecology: danger of deep-sea mining. Science 316, 987-987. doi:10.1126/science.1138289

Halfar, J., Fujita, R.M., 2002. Precautionary management of deep-sea mining. Mar. Policy 26, 103106. doi:10.1016/S0308-597X(01)00041-0

Hannington, M., Monecke, T., 2009. Global exploration models for polymetallic sulphides in the area: an assessment of lease block selection under the draft regulations on prospecting and exploration for polymetallic sulphides. Mar. Georesources Geotechnol. 27, 132-159. doi:10.1080/10641190802680614

Hecker, B., 1985. Fauna from a cold sulfur-seep in the gulf of Mexico: comparison with hydrothermal vent communities and evolutionary implications, in: Bulletin of the Biological Society of Washington. Presented at the Hydrothermal vents of the eastern Pacific: an overview. Symposium, National Museum of Natural History, Biological Society of Washington, pp. 465473. 


\section{ACCEPTED MANUSCRIPT}

Herzig, P.M., Hannington, M.D., 1995. Polymetallic massive sulfides at the modern seafloor a review.

Ore Geol. Rev. 10, 95-115. doi:10.1016/0169-1368(95)00009-7

Hoagland, P., Beaulieu, S., Tivey, M.A., Eggert, R.G., German, C., Glowka, L., Lin, J., 2010. Deep-sea mining of seafloor massive sulfides. Mar. Policy 34, 728-732. doi:10.1016/j.marpol.2009.12.001

Huvenne, V.A., Beyer, A., de Haas, H., Dekindt, K., Henriet, J.-P., Kozachenko, M., Olu-Le Roy, K., Wheeler, A.J., others, 2005. The seabed appearance of different coral bank provinces in the Porcupine Seabight, NE Atlantic: results from sidescan sonar and ROV seabed mapping, in: Cold-Water Corals and Ecosystems. Springer, pp. 535-569.

Huvenne, V.A.I., Tyler, P.A., Masson, D.G., Fisher, E.H., Hauton, C., Hühnerbach, V., Le Bas, T.P., Wolff, G.A., 2011. A picture on the wall: innovative mapping reveals cold-water coral refuge in submarine canyon. PLoS ONE 6, e28755. doi:10.1371/journal.pone.0028755

Jones, G.E., Cumming, R.E., Hunt, P.R., 2005. The use of remote sensing techniques for the location and investigation of heritage wreck sites, in: Transactions on the Built Environment. Presented at the International Conference on Maritime Engineering, Ports and Waterways, pp. 185-194.

Kostylev, V.E., Courtney, R.C., Robert, G., Todd, B.J., 2003. Stock evaluation of giant scallop (Placopecten magellanicus) using high-resolution acoustics for seabed mapping. Fish. Res. 60, 479-492. doi:10.1016/S0165-7836(02)00100-5

Kostylev, V.E., Todd, B.J., Fader, G.B., Courtney, R.C., Cameron, G.D., Pickrill, R.A., 2001. Benthic habitat mapping on the Scotian Shelf based on multibeam bathymetry, surficial geology and sea floor photographs. Mar. Ecol. Prog. Ser. 219, 121-137.

Krylova, E.M., Cosel, R.V., 2011. A new genus of large Vesicomyidae (Mollusca, Bivalvia, Vesicomyidae, Pliocardiinae) from the Congo margin, with the first record of the subfamily Pliocardiinae in the Bay of Biscay (northeastern Atlantic). Zoosystema 33, 83-99. doi:10.5252/z2011n1a4 


\section{ACCEPTED MANUSCRIPT}

Le Gal, L., Edy, C., 1997. CARAIBES: an integrated software for multibeam echosounder and sidescan sonar data mapping, in: OCEANS '97. MTS/IEEE Conference Proceedings. Presented at the OCEANS '97. MTS/IEEE Conference Proceedings, pp. 1242-1245 vol.2.

doi:10.1109/OCEANS.1997.624173

MacDonald, I.R., Boland, G.S., Baker, J.S., Brooks, J.M., li, M.C.K., Bidigare, R.R., 1989. Gulf of Mexico hydrocarbon seep communities II Spatial distribution of seep organisms and hydrocarbons at Bush Hill. Mar. Biol. 101, 235-247. doi:10.1007/BF00391463

MacDonald, I.R., Jr, N.L.G., Reilly, J.F., Brooks, J.M., Callender, W.R., Gabrielle, S.G., 1990a. Gulf of Mexico hydrocarbon seep communities: VI. Patterns in community structure and habitat. Geo-Mar. Lett. 10, 244-252. doi:10.1007/BF02431071

MacDonald, I.R., Reilly, J.F., Guinasso, N.L., Brooks, J.M., Carney, R.S., Bryant, W.A., Bright, T.J., 1990b. Chemosynthetic mussels at a brine-filled pockmark in the northern Gulf of Mexico. Science 248, 1096-1099. doi:10.1126/science.248.4959.1096

Marcon, Y., Ondreas, H., Sahling, H., Bohrmann, G., Olu, K., 2013a. Fluid flow regimes and growth of a giant pockmark. Geology 42, 63-66. doi:10.1130/G34801.1

Marcon, Y., Sahling, H., Allais, A.-G., Bohrmann, G., Olu, K., 2014. Distribution and temporal variation of mega-fauna at the Regab pockmark (Northern Congo Fan), based on a comparison of videomosaics and geographic information systems analyses. Mar. Ecol. 35, 77-95. doi:10.1111/maec.12056

Marcon, Y., Sahling, H., Bohrmann, G., 2013b. LAPM: a tool for underwater large-area photomosaicking. Geosci. Instrum. Methods Data Syst. 2, 189-198. doi:10.5194/gi-2-189-2013 McGonigle, C., Brown, C., Quinn, R., Grabowski, J., 2009. Evaluation of image-based multibeam sonar backscatter classification for benthic habitat discrimination and mapping at Stanton Banks, UK. Estuar. Coast. Shelf Sci. 81, 423-437. doi:10.1016/j.ecss.2008.11.017 


\section{ACCEPTED MANUSCRIPT}

Micallef, A., Berndt, C., Masson, D.G., Stow, D.A.V., 2007. A technique for the morphological characterization of submarine landscapes as exemplified by debris flows of the Storegga Slide. J. Geophys. Res. Earth Surf. 112, F02001. doi:10.1029/2006JF000505

Micallef, A., Le Bas, T.P., Huvenne, V.A.I., Blondel, P., Hühnerbach, V., Deidun, A., 2012. A multimethod approach for benthic habitat mapping of shallow coastal areas with high-resolution multibeam data. Cont. Shelf Res. 39-40, 14-26. doi:10.1016/j.csr.2012.03.008

Miyazaki, J.-I., Martins, L. de O., Fujita, Y., Matsumoto, H., Fujiwara, Y., 2010. Evolutionary process of deep-sea Bathymodiolus mussels. PLoS ONE 5, e10363. doi:10.1371/journal.pone.0010363

Moustier, C. de, 1986. Beyond bathymetry: Mapping acoustic backscattering from the deep seafloor with Sea Beam. J. Acoust. Soc. Am. 79, 316-331. doi:10.1121/1.393570

Olu-Le Roy, K., Caprais, J.-C., Fifis, A., Fabri, M.-C., Galéron, J., Budzinsky, H., Le Ménach, K., Khripounoff, A., Ondréas, H., Sibuet, M., 2007a. Cold-seep assemblages on a giant pockmark off West Africa: spatial patterns and environmental control. Mar. Ecol. 28, 115-130. doi:10.1111/j.1439-0485.2006.00145.x

Olu-Le Roy, K., Cosel, R. von, Hourdez, S., Carney, S.L., Jollivet, D., 2007b. Amphi-Atlantic cold-seep Bathymodiolus species complexes across the equatorial belt. Deep Sea Res. Part Oceanogr. Res. Pap. 54, 1890-1911. doi:10.1016/j.dsr.2007.07.004

Ondréas, H., Olu, K., Fouquet, Y., Charlou, J.L., Gay, A., Dennielou, B., Donval, J.P., Fifis, A., Nadalig, T., Cochonat, P., Cauquil, E., Bourillet, J.F., Moigne, M.L., Sibuet, M., 2005. ROV study of a giant pockmark on the Gabon continental margin. Geo-Mar. Lett. 25, 281-292. doi:10.1007/s00367-005-0213-6

Orange, D.L., Yun, J., Maher, N., Barry, J., Greene, G., 2002. Tracking California seafloor seeps with bathymetry, backscatter and ROVs. Cont. Shelf Res., Gas in Marine Sediments: Contributions from the 5th International Conference orgainsed by the Shallow Gas Group, Bologna, Italy, September 1998 22, 2273-2290. doi:10.1016/S0278-4343(02)00054-7 


\section{ACCEPTED MANUSCRIPT}

Papatheodorou, G., Geraga, M., Ferentinos, G., 2005. The Navarino naval battle site, Greece-an integrated remote-sensing survey and a rational management approach. Int. J. Naut. Archaeol. 34, 95-109. doi:10.1111/j.1095-9270.2005.00047.x

Pickrill, R.A., Todd, B.J., 2003. The multiple roles of acoustic mapping in integrated ocean management, Canadian Atlantic continental margin. Ocean Coast. Manag. 46, 601-614. doi:10.1016/S0964-5691(03)00037-1

Pierre, C., Fouquet, Y., 2007. Authigenic carbonates from methane seeps of the Congo deep-sea fan. Geo-Mar. Lett. 27, 249-257. doi:10.1007/s00367-007-0081-3

Ramirez-Llodra, E., Tyler, P.A., Baker, M.C., Bergstad, O.A., Clark, M.R., Escobar, E., Levin, L.A., Menot, L., Rowden, A.A., Smith, C.R., Van Dover, C.L., 2011. Man and the last great wilderness: human impact on the deep sea. PLoS ONE 6, e22588. doi:10.1371/journal.pone.0022588

Roberts, C.M., 2002. Deep impact: the rising toll of fishing in the deep sea. Trends Ecol. Evol. 17, 242245. doi:10.1016/S0169-5347(02)02492-8

Roberts, J.M., Brown, C.J., Long, D., Bates, C.R., 2005. Acoustic mapping using a multibeam echosounder reveals cold-water coral reefs and surrounding habitats. Coral Reefs $24,654-$ 669. doi:10.1007/s00338-005-0049-6

Rona, P.A., 2003. Resources of the sea floor. Science 299, 673-674.

Savini, A., Corselli, C., 2010. High-resolution bathymetry and acoustic geophysical data from Santa Maria di Leuca Cold Water Coral province (Northern Ionian Sea-Apulian continental slope). Deep Sea Res. Part II Top. Stud. Oceanogr. 57, 326-344. doi:10.1016/j.dsr2.2009.08.014

Scott, K.M., Fisher, C.R., 1995. Physiological ecology of sulfide metabolism in hydrothermal vent and cold seep vesicomyid clams and vestimentiferan tube worms. Am. Zool. 35, 102-111. doi:10.2307/3883967

Sigvaldadottir, E., Mackie, A.S.Y., Helgason, G.V., 2003. Advances in polychaete research. Springer Science \& Business Media. 


\section{ACCEPTED MANUSCRIPT}

Simeoni, P., Sarrazin, J., Nouze, H., Sarradin, P.-M., Ondreas, H., Scalabrin, C., Sinquin, J.-M., 2007.

Victor 6000: New high resolution tools for deep sea research. « Module de Mesures en Route ». Oceans 2007 - Eur. Vols 1-3 133-138.

Singh, H., Adams, J., Mindell, D., Foley, B., 2000. Imaging underwater for archaeology. J. Field Archaeol. 27, 319-328. doi:10.1179/jfa.2000.27.3.319

Smith, E.B., Scott, K.M., Nix, E.R., Korte, C., Fisher, C.R., 2000. Growth and condition of seep mussels (Bathymodiolus childressi) at a Gulf of Mexico brine pool. Ecology 81, 2392-2403. doi:10.1890/0012-9658(2000)081[2392:GACOSM]2.0.CO;2

Southward, E.C., 2000. Class Pogonophora, in: Beesley, P. L., Ross, G. L. B., Glasby, C. J. (Eds.), Polychaetes and Allies: The Southern Syntehsis Fauna of Australia. CSIRO Publishing, Melbourne, pp. 331-351.

Southward, E.C., Schulze, A., Gardiner, S.L., 2005. Pogonophora (Annelida): form and function. Hydrobiologia 535/536, 227-251.

Todd, B.J., 2005. Morphology and composition of submarine barchan dunes on the Scotian Shelf, Canadian Atlantic margin. Geomorphology 67, 487-500. doi:10.1016/j.geomorph.2004.11.016

Todd, B.J., Fader, G.B.J., Courtney, R.C., Pickrill, R.A., 1999. Quaternary geology and surficial sediment processes, Browns Bank, Scotian Shelf, based on multibeam bathymetry. Mar. Geol. 162, 165-214. doi:10.1016/S0025-3227(99)00092-4

Tsurumi, M., 1998. The application of Geographical Information Systems to biological studies at hydrothermal vents. Cah. Biol. Mar. 39, 263-266.

Van Dover, C.L., 2011. Tighten regulations on deep-sea mining. Nature 470, 31-33.

von Cosel, R., Olu, K., 2009. Large Vesicomyidae (Mollusca: Bivalvia) from cold seeps in the Gulf of Guinea off the coasts of Gabon, Congo and northern Angola. Deep Sea Res. Part II Top. Stud. Oceanogr., Deep-Sea Benthic Ecosystems of the Equatorial African Margin: The 


\section{ACCEPTED MANUSCRIPT}

Multidisciplinary BIOZAIRE Program A Contribution to Census of Marine Life 56, 2350-2379. doi:10.1016/j.dsr2.2009.04.016

Von Cosel, R., Olu, K., 2008. A new genus and new species of Vesicomyidae (Mollusca, Bivalvia) from cold seeps on the Barbados accretionary prism, with comments on other species. Zoosystema 30, 929-944.

Von Damm, K.L., 1990. Seafloor Hydrothermal Activity: Black Smoker Chemistry and Chimneys. Annu. Rev. Earth Planet. Sci. 18, 173-204. doi:10.1146/annurev.ea.18.050190.001133

Wilson, M.F.J., O'Connell, B., Brown, C., Guinan, J.C., Grehan, A.J., 2007. Multiscale terrain analysis of multibeam bathymetry data for habitat mapping on the continental slope. Mar. Geod. 30, 335. doi:10.1080/01490410701295962

Zandbergen, P.A., 2009. Accuracy of Iphone locations: a comparison of assisted GPS, wifi and cellular positioning. Trans. GIS 13, 5-25. doi:10.1111/j.1467-9671.2009.01152.x

Zandbergen, P.A., Barbeau, S.J., 2011. Positional accuracy of assisted GPS data from high-sensitivity GPS-enabled mobile phones. J. Navig. 64, 381-399. doi:10.1017/S0373463311000051 
Supplementary Figures
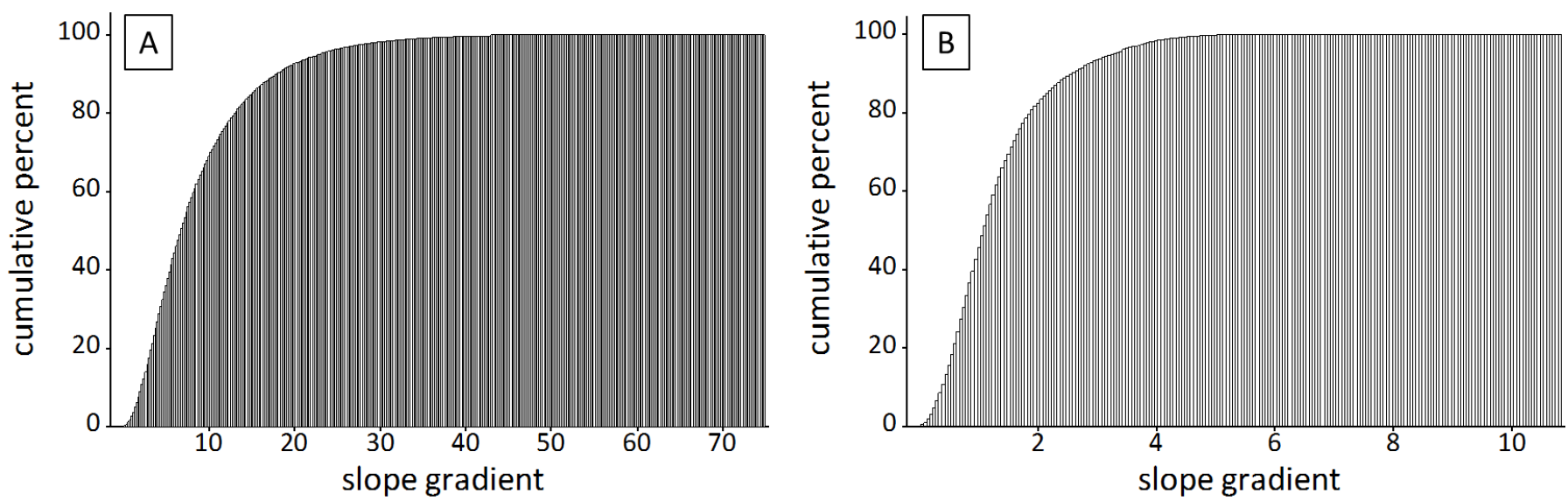

Supplementary Figure 1: Cumulative frequency of exported values of slope gradient for the $8 \mathrm{~m}$ altitude dataset $(\mathrm{A})$ and the $30 \mathrm{~m}$ altitude dataset (B). 


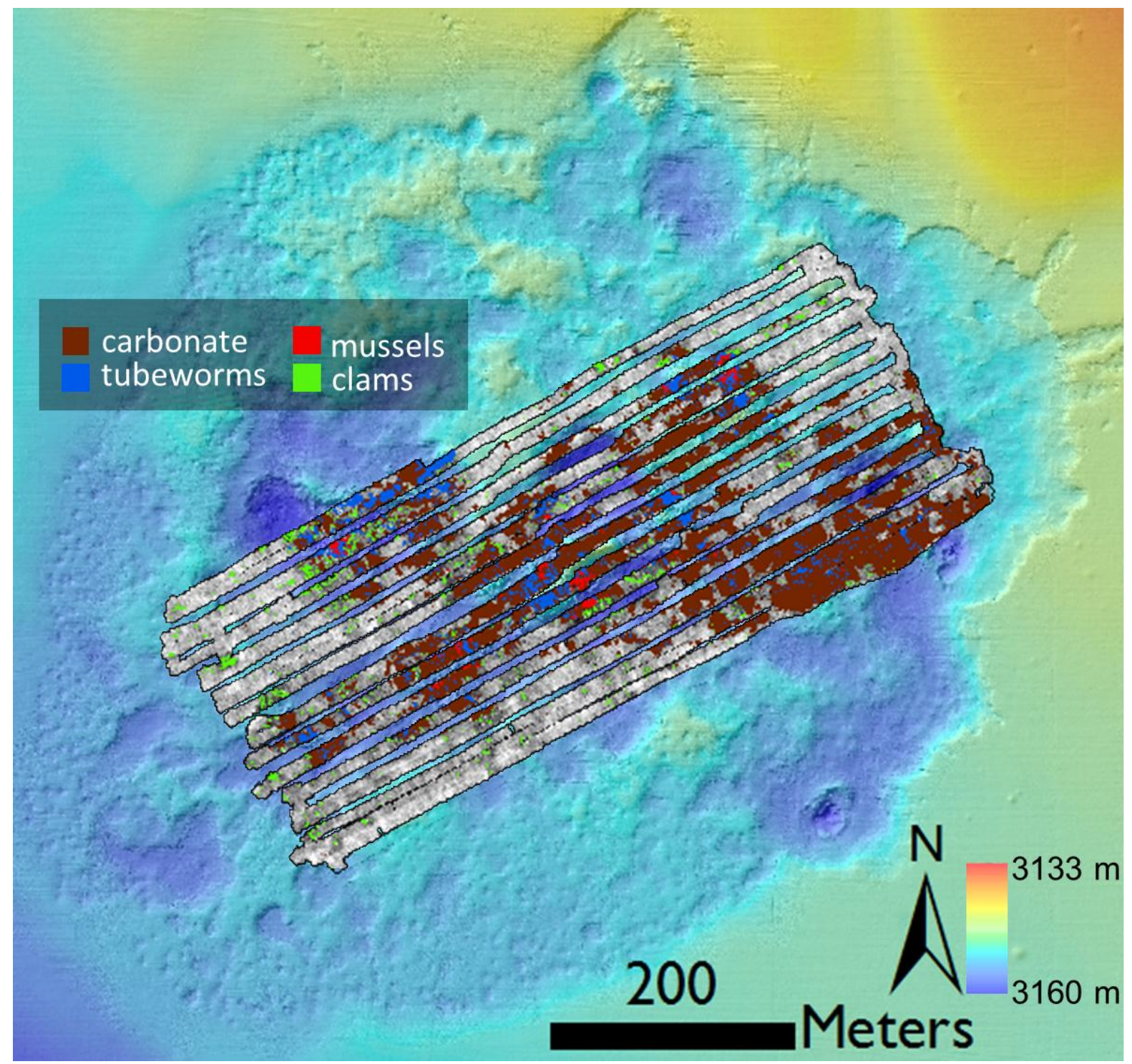

Supplementary Figure 2: The OTUS photomosaic with the four major faunal groups and carbonate marked. 

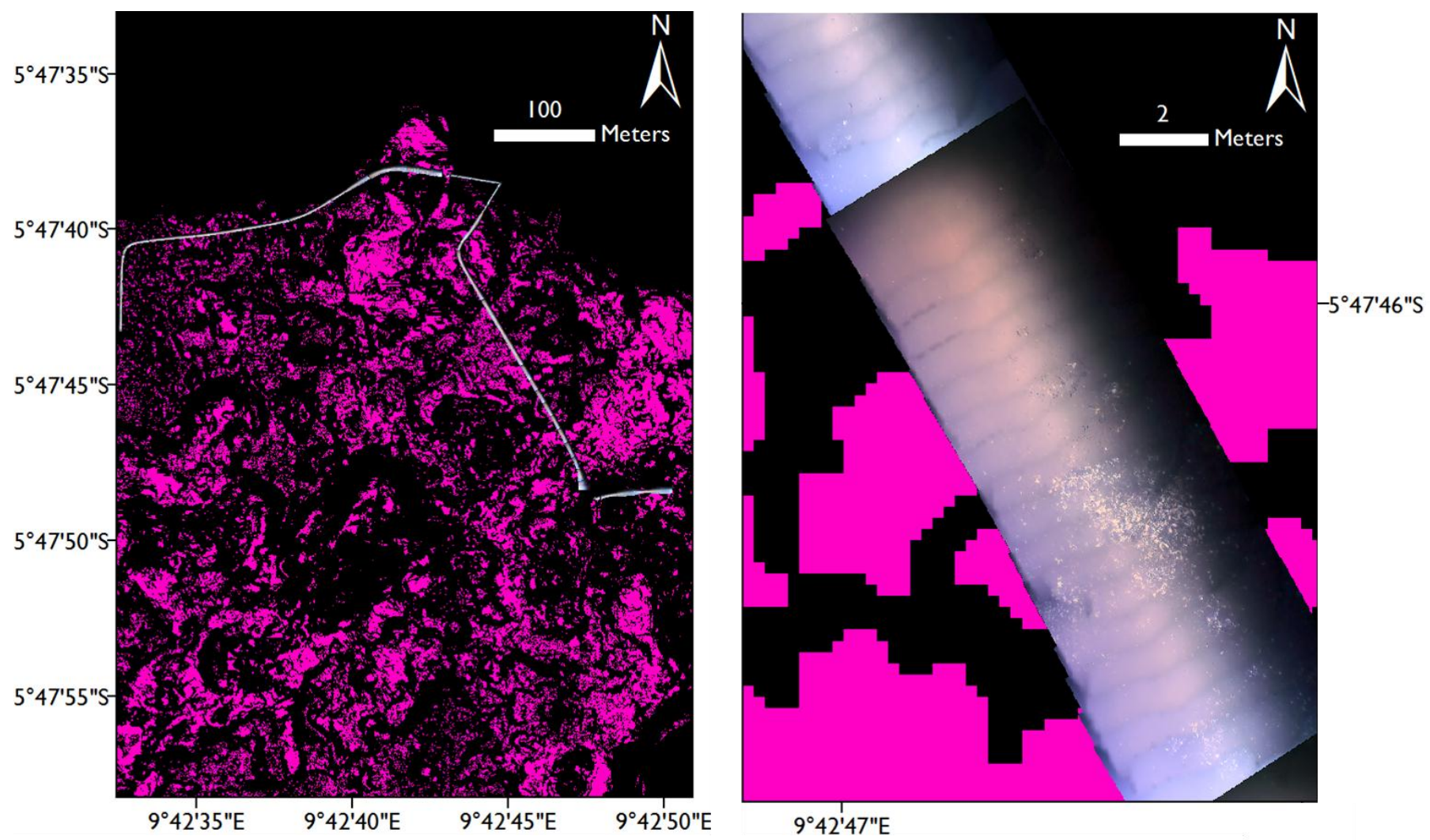

Supplementary Figure 3: The dive 429 photomosaic and a close up of a portion of the photomosaic, showing the reliability of clam predicted distributions (in pink). 